\title{
NIHILISMO COMPARATIVO
}

\author{
COMPARATIVE NIHILISM
}

Flávio R. Kothe

Professor titular de Estética na FAU/UnB.

\begin{abstract}
RESUMO
É necessário desenvolver o que no momento poderíamos chamar de uma "comparatística nihilista", ou seja, sempre ter uma noção do que não foi desenvolvido por uma obra de arte ou um ensaio filosófico. A comparação de obras com pontos estratégicos de similaridade é um primeiro passo para isso, mas nós precisamos considerar uma parte obscura da obra para entender a sua configuração, as suas características, a sua qualidade. O "abscôndito" é uma parte da obra, assim como temos um lado da Lua que normalmente não vemos. Isso significa que deveríamos permitir a imaginação ser uma parte da hermenêutica.
\end{abstract}

Palavras-chave: Arte Comparada; Nihilismo; Hermenêutica; Heidegger; Celan.

\section{ABSTRACT}

It is necessary to develop what we could call at the moment a "nihilist comparative", that is to say, always to have a notion of what was not developed by a work of art or a philosophical essay. The comparison of works with strategical points of similarity is a first step to it, but we need to consider to shadowy part of the work to understand its configuration, its characteristic, its quality. The "absconditus" is a part of the work, as we have a side of the Moon that we normally do not see. It means we should allow imagination to be a part of hermeneutics.

Keywords: Comparative Art; Nihilism; Hermeneutics; Heidegger; Celan.

\section{Introito}

Quando questões teóricas - e mesmo práticas - são propostas sem fundamentação na metafísica, elas se revelam superficiais e inconsistentes. Nela vai se dar a discussão de como se entende o ser humano, o que poderia ser o "cosmos" no qual se encontra e desencontra, quais são os valores mais relevantes que guiam sua visão de mundo e sua ação. A metafísica tem estado fora de moda em vários momentos, especialmente quando se supõe que ela possa ser substituída pelo catecismo e pela doutrinação catequética.

No Brasil, apenas na década de 1960 surgiram seus primeiros afloramentos mais críticos na universidade, que foram perseguidos e quase extintos em 1969, com o AI-5. Isso fazia parte da perseguição milenar movida pela teologia católica, que supunha ter todas as respostas. O catecismo finge ser feito à base de perguntas e respostas, mas a pergunta só serve para propiciar a resposta, em que se substitui o

${ }^{1}$ Wolff, Christian. Erste Philosophie oder Ontologie, Hamburg, Felix Meiner Verlag, 2005, uebersetzt und herausgegeben von Dirk Effertz. questionamento pelas "verdades da fé". Quando essa doutrina se mostrou insuficiente e inconsistente, surgiu o impulso crítico da metafísica, que sofreu a revanche de um movimento como a TFP, Tradição, Família e Propriedade. Isso redobrou o atraso existente, até hoje não recuperado, e afeta todas as áreas de conhecimento teórico.

A metafísica não se volta diretamente para a política, mas ela tem consequências políticas e éticas. Ela tem sido dividida em três partes específicas: a psicologia, como estudo do homem; a teologia, como estudo de deus; a cosmologia, como estudo do cosmos. E uma parte geral, a ontologia, ou filosofia primeira. Já Christian Wolff' ${ }^{1}$ se queixava, na primeira metade do século XVIII, que a metafísica parecia fora de moda, desde que passara a prevalecer o pensamento cartesiano. Ele tratou então de escrever uma "Filosofia Primeira", aplicando princípios cartesianos ao estudo dela. Chegou, no \# 77, à importante questão de saber se tudo aquilo que vemos, como vemos, no sentido que vemos, é produto de nossa imaginação, de uma capacidade de fabulação que nos dominaria. Ele abriu aí um caminho 
que foi sugestivo para Kant, na primeira edição da Crítica da razão pura, bem como para Schopenhauer, Nietzsche e Heidegger.

O esforço feito por Heidegger, impulsionado por Nietzsche e até mesmo por Marx, no sentido de superar a estrutura da tradição metafísica como prisão do pensamento, não impede que se recaia nela, mesmo sem querer. Como sugeriu Wittgenstein, chega o momento em que, impulsionado pelo autor, é preciso ir além dele, passando por ele, para não ficar aquém de seu percurso, exatamente o que não fazem os bons discípulos. Para captar o grande texto, a hermenêutica precisa ir além dele, regredir até o seu projeto potencial, para confrontar o que poderia ter sido feito com aquilo que chegou a ser realizado, a fim de entender o horizonte diferencial delineado por ele. A leitura da obra difícil precisa ir até o nada da obra para chegar até ela.

No Brasil, sob a aparência de se estar divulgando a obra de Heidegger, ela está sendo sabotada no seu sentido primordial por erros sistemáticos de tradução dos seus termos básicos. ${ }^{2}$ Toda vez que, em alemão, se tem a combinação do verbo Sein com preposições como da, mit, zu ou in, ele precisa ser traduzido para o português, ao contrário do que tem acontecido, por "estar" e não por "ser": assim, Dasein = estar aí e não ser aí, mitsein = estar com e não ser com, sein zum Tode = estar para a morte e não ser para a morte, in der Welt sein = estar no mundo e não ser no mundo. Não é um simples engano de tradução. Nela se é antes de estar, já é antes o que está aí. Como se houvesse um ser anterior à vida concreta, uma alma antes de um corpo, um espírito antes qualquer matéria.

Faz-se a essência preceder a existência, volta-se ao neoplatonismo que pretendia ser superado. A tradução é católica. Ele tem sido lido catolicamente. Isso é reforçado no Heidegger II, quando ele fala no advento do "último dos deuses", o que faz ressoar campainhas e missais, embora ele diga que não pretende chamar com isso um deus cristão. Muitos professores de filosofia no Brasil tiveram formação católica de seminário, estavam a caminho de ser padres, jesuítas se possível. Essa é uma luta antiga, da qual o grupo de Port Royal sofreu as piores consequências.

São dois modos antitéticos de ver o mundo: ou se tem um mundo das ideias, proposto por Platão como hipótese através de Sócrates na República e posto pelo cristianismo na mente divina, feito de protótipos, do qual as coisas que existem no mundo são meras cópias mais ou menos exatas, ou então o que está na mente humana é o reflexo das coisas que já existem na realidade. A reflexão deriva do reflexo, não o real de uma mente, por mais que ele seja permeado pelos condicionantes dela. Na própria República, no final, Platão rejeita a teoria que leva o seu nome: Sócrates diz no fim que se pode criar um equivalente ao mundo das ideias saindo pelo campo com um enorme espelho, no qual se reflitam as árvores, as nuvens, os pássaros, o próprio sujeito. Platão descarta o platonismo: primeiro existem as coisas reais, os fatos, depois se reflete sobre isso e se faz um constructo mental, um mundo de protótipos. O cristianismo não: para ele, real mesmo é a ideia na mente divina, a "realidade" é mera cópia ocasional: se Deus quiser, pode desfazer tudo o que já se fez e criar outros mundos a partir do nada. O homem está na mão de Deus, que é todo poderoso. O homem é um verme, cuja única salvação é ajoelhar. Estranhamente, Heidegger não insiste nisso. Ele não vê defeito nos seus queridos gregos.

Ora, os antigos gregos não tinham noção de estrelas que explodem, de buracos negros, de estrelas novas, da distância entre as constelações. Seu conceito de "verdade", "alétheia", se forma a partir de uma dupla negação, o alfa privans e o olvido, ou seja, ela é algo como "desolvido". Ora, para isso é preciso que alguém já tenha sabido antes, cabendo então fazer a linguagem parir o saber que se escondeu na língua. Quem garante, porém, que já se soubesse antes? Mesmo que se diga "desencobrir", é preciso que alguém tenha encoberto, para que outro faça a "descoberta". Daí não se cria nada, nada novo surge, tudo é filologia e hermenêutica. A realidade que se dane.

Para nós, o contrário de verdadeiro é falso, mas os gregos usavam o termo "pseudos", que aparece em pseudônimo, um nome que não é falso, mas outro nome que se usa no lugar do autêntico: é preciso passar por sua aparência para chegar ao verdadeiro. No início da República, aquele, não qualquer aquele e sim apenas o aristocrata candidato a governante, aquele que sai da caverna precisa descobrir que a opinião, a "doxa", de que o Sol gira em torno da Terra (se possível levado por Apolo), deve ser superada pela "episteme", uma doutrina egípcia de que a Terra é que gira em torno do Sol, sendo este o centro de tudo (como era centro de tudo o faraó que o corporificava e representava). Essa "episteme" também é falsa. Estranhamente, Heidegger não discute isso, como se não quisesse que a ciência moderna pudesse ter ultrapassado os seus preciosos gregos antigos.

Outra questão se coloca nos primórdios da Metafísica. Heidegger observa que o sentido original do "ser" no grego antigo era antes "estar" do que ser, mesmo que a língua grega - como também as demais "línguas filosóficas", latim, francês, alemão e inglês - não façam a distinção que há em português e espanhol. Talvez por causa do dogmatismo católico, nestas não surgiram

${ }^{2}$ Heidegger, Martin. Ser e tempo, Petrópolis e Campinas, Ed. Vozes com Ed. Unicamp, 2012, tradução de Fausto Castilho. 
ainda filósofos capazes de gerar uma nova terminologia e visão de mundo. Seria necessário, por exemplo, inventar um termo como "estante" para estar e "havente" para haver assim como há ente para ser.

Esses termos não existem para os filósofos de língua portuguesa, seriam palpites infelizes de quem não é competente. Se o estar é constitutivo do ser, o estar está para o espaço assim como o ser para o tempo. Não existe alma sem corporeidade. O espaço é constitutivo da finitude do ser humano. Para os arquitetos, parece natural que assim seja.

Na leitura de Heidegger, o "ser" foi entendido na Grécia como aquilo que está aí para nós, os humanos. Por estar, aparece, tendo de se descobrir, em meio às aparências, o que é aquilo que está aí. Acaba sendo aquilo que se diz ser a coisa, ou seja, desde o início se consagra como "ser" aquilo que se pensa e se afirma. O termo "logos" significa ao mesmo tempo pensamento e discurso: essa confusão é fundamental, esconde que as palavras podem servir para mentir, para não dizer o que as coisas sejam, para desviar a atenção para o lateral, escamoteando o fundamental.

Essa deformação inicial recebeu um impulso enorme com o judaísmo, para o qual, no início, havia o Verbo, sendo que as coisas surgem por palavras de Jeová: "Deus disse: faça-se a luz, e a luz se fez". O catolicismo endossou isso, fez do latim erudito a palavra divina, impediu que o povo tivesse acesso ao texto sagrado. As coisas derivam do pensamento e do seu discurso. A verdade se desloca da aparição da coisa para o que se diz sobre ela. Quando Lutero tornou a palavra bíblica mais acessível aos alemães, ele não rompeu com a crença de que a Bíblia fosse um texto sagrado, a contar o que realmente teria se passado no mundo judaico antigo.

Um poder totalitário impõe que as coisas sejam vistas como ele diz que são e como ele quer que sejam vistas. Com o cristianismo, essa tendência foi divinizada, Cristo aparece como o "Verbo que se fez carne e habitou entre nós". A palavra foi posta publicamente num púlpito, num plano mais elevado, entre a terra e o céu, o orador sacro não podia nem pode ser interrompido nem rebatido. Daí é fácil chegar ao passo seguinte: fazer daquilo que se crê um "dever ser" não só para nós que cremos, mas para todos os que queremos "salvar", interferindo em sua existência a pretexto da salvação.

Hegel propõe a literatura como a mais elevada das artes, sendo a poesia a mais elevada das elevadas. Poderia ter dito que o teatro, no diálogo de um tu com um tu, poderia ter mais abertura para alternativas. Para ele, a arquitetura era a mais grosseira das linguagens artísticas, incapaz de dizer a que veio, precisando do auxílio da literatura. Essa pode ser uma leitura grosseira, uma não compreensão do que é mais peculiar a essa linguagem.

Heidegger acha que só na poesia é que a filosofia vai encontrar uma parceira para as suas perquirições. Ele quase admite que o grande poeta precede o filósofo. Os dois são parceiros no uso da palavra e, portanto, no descarte de outras linguagens. Quando ele se preocupa com a revelação do "Seyn", por que não consegue perceber que a música e a grande arquitetura talvez tenham mais condições de sugeri-lo do que a palavra?

Estamos numa sociedade dominada por essa visão religiosa, que ontifica o ontológico e acaba levando ao esquecimento do havente, mas ela é complementada pela ciência, pela tecnologia, pela correria do cotidiano, pelo embotamento da "gente". A ciência só quer saber do que pode ser observado, embora a todo o momento tenha de observar que não pode observar muitas coisas. A técnica é o peão da ciência, a empregada que aplica em entes as invenções da ciência. No dia a dia não temos tempo para matutar sobre o que não percebemos: já são demais os problemas que nos aparecem. O "embotamento" é mais que miopia. O míope não enxerga bem o que fica mais distante, mas ao menos enxerga o que fica perto. O "embotamento" ocorre também na forma de hipermetropia, de não se poder ver bem o que fica perto.

Somos, contudo, naturalmente obtusos nas duas direções: tanto na direção do infinitamente grande quanto do infinitamente pequeno. Quanto mais desenvolvemos aparelhagens para enxergar nas duas direções, tanto mais se descobre que ainda há mais a ver. Pascal entendeu o homem como um "entre" o infinitamente grande e o infinitamente pequeno, ou seja, a compreensão do "cosmos" e do transcendental levam a uma redefinição do homem. Mas há mais: há muita coisa que nem sequer aparece para o ser humano e nem por isso deixa de existir e de ter a sua natureza. Nietzsche percebeu isso, quando falou da luz de uma estrela extinta que ainda chega até nós; e de uma nova estrela, cuja luz ainda não chegou até a Terra (ela há, mas não está aí para nós, não sabemos o que ela é). Quais são seus modos de existência?

Não é porque o homem diz que algo é; não é porque algo não aparece que isso não é. Está fora do alcance homem, mas é o que é, independente do fenômeno ocasional e transitório que é o ser humano. Este não é o centro do universo, nem sequer existe universo, uma elipse que dê a volta sobre si, feita a partir de dois centros e formando um todo fechado. Achamos que tudo tem limite, pois nosso conhecimento é limitado: 
só conseguimos pensar finitudes, tendo, todavia, abertura para a infinitude. Se a luz de uma estrela não chegou à Terra, isso não quer dizer que essa estrela não existe, não seja o que ela é. Ela não está aí para nós, nós não estamos nem aí para ela, ela existe sem fazer parte de nossa existência. Ela é apenas uma hipótese de existência: existe como poder ser.

Se a luz de uma estrela que já acabou continua chegando à Terra, isso não faz que a estrela como tal continue existindo só porque sua luz se manifesta a nós e nos faz parecer que a própria estrela existe. A ciência moderna descobriu muitos modos de existência - raios gama, raios ultravioleta e infravermelho, raios X, etc. - que não são percebidos normalmente por nossos sentidos e dos quais os antigos não tinham noção. Talvez nem tudo o que existe pelos espaços siderais seja "coisa", uma res extensa, um corpo. Pode haver pura energia, pode haver a antimatéria, pode haver aquilo para o que não temos nem a sugestão de um nome ainda.

\section{Ressalvas a Heidegger}

Heidegger tendeu a criticar a tecnologia e a menosprezar a ciência, pois seriam coroamentos da tradição metafísica. Ele não viu a duplicidade de ambas, pois tanto a reproduzem quanto são uma abertura para o ignoto, lançam hipóteses e fazem pesquisas sobre o que seria o "transcendental", o que está além da percepção habitual. Elas são, e tem de se dado nos limites das estruturas dessa tradição, mas, ao mesmo tempo, têm gerado a possibilidade de com mais solidez se avançar a pesquisa sobre aquilo que não vemos, que não aparece aos nossos sentidos, que não está ao alcance da nossa percepção e do nosso conhecimento.

Dominado por uma visão apolínea da cultura grega parece que não vê problema em ela ter sido calcada no trabalho escravo, sido permeada de crendices idiotas, deuses inventados e falsos, ter perseguido e assassinado vários dos seus melhores intelectuais -, Heidegger não consegue superar o modelo grego de sua adoração. Torna-se um comentador de Platão e Aristóteles, não sua superação. Ainda estamos aguardando o advento do grande pensador desse horizonte novo, e este não vai ser alguém com menos estofo que Descartes, Kant, Hegel, Nietzsche e Heidegger.

Heidegger recai num série deslize ao falar com insistência no "último dos deuses", como aquele que seria o enunciador do "Seyn", o Ser além do ser. ${ }^{3}$ Todo último dos deuses precisa de um próximo deus, que o delimite como deus: ele se torna, portanto, o penúltimo antes do próximo último, ad infinitum, como quando
Aristóteles diz que todo corpo é envolvido por outro corpo maior: não se consegue chegar ao último, a não ser pela fantasia de um deus posto fora do sistema e que poderia contemplar o universo de sua criação. Com isso ele se abre para uma nova teologia, que é saudada com fervor pelos tantos supostos filósofos profissionais, que em geral frequentaram seminários e cursos de teologia católicos (como o próprio Heidegger) e caem de joelhos quando ouvem o tilintar de campainhas. Que uma criança tenha sido obrigada pelos pais e pela escola a frequentar cultos religiosos e se deixar doutrinar numa crendice qualquer, não justifica que o adulto continue a repetir isso, abdicando da razão crítica.

Essa recaída na teologia faz do discurso dito filosófico uma racionalização da crença pré-crítica. A esperança da renovação filosófica parece sair do âmbito do filósofo profissional, do professor de filosofia. Mais importa o filosofar do que lecionar filosofia. As grandes questões são as mesmas e não se resolvem com tecnicismo nem com erudição, embora não prescindam disso. Há uma tradição, há obras clássicas que precisam ser conhecidas, e bem compreendidas para ousar um passo adiante. Nenhum filósofo ou cientista é um deus, por mais que a ignorância alheia e a vaidade própria o estimulem a ser. Heidegger anuncia o advento do "último dos deuses" para poder ser ao menos o seu João Batista e virar santo, um penúltimo deus, a suceder um antepenúltimo.

Quando Aristóteles usou o termo "theos" para designar aquelas instâncias mais elevadas, que transcendem o horizonte da percepção humana, ele não estava pensando no deus cristão, já porque não tinha noção do que se inventaria em torno disso depois dele, mas também já cometeu o erro de mistificar o que deveria ser investigado pela ânsia humana de conhecer. Foi uma perversão no sentido de abdicar da razão crítica. Ele podia ter em mente deuses como Saturno, Cronos e Zeus que, na teogonia grega, teriam sido os grandes agentes transformadores do caos em cosmos.

\section{Teoria literária $\mathrm{x}$ filosofia}

Quando Gadamer sugeriu que a hermenêutica filosófica deveria se distinguir por ser capaz de discutir seus próprios pressupostos, acenou um otimismo no qual os filósofos profissionais se inclinam a acreditar. Com isso, supõem ser superiores aos hermeneutas jurídicos, que ficam presos aos pressupostos e aos ditames do direito positivo, e aos hermeneutas teológicos, que, por mais que aticem argumentos, sempre acabam

${ }^{3}$ Heidegger, Martin. Beiträge zur Philosophie (Vom Ereignis), Frankfurt a.M., Klostermann Verlag, 2a edição, 1994. 
retornando aos pressupostos de suas crenças. 0 filósofo achar que ultrapassou seus pressupostos e preconceitos apenas por ser filósofo é um modo de não enfrentar a questionabilidade deles. Ele pode se desviar para preconceitos menores e, com isso, achar que já fez o grande questionamento, quando exatamente fugiu a ele se desviando para o menos relevante e menos perturbador.

A arte egípcia antiga foi produzida durante três milênios obedecendo às mesmas regras ditadas pela casta sacerdotal, como a de que o faraó tinha de ser a figura maior e ser apresentado de perfil, de tal maneira que logo ela pode ser identificada como tal. No reinado de Tutancâmon, de cerca de 17 anos, houve uma exceção e se pode ver o faraó recebendo um filho nos braços ou se movimentando numa caçada, o que acompanhava a mudança teológica do politeísmo ao monoteísmo nesse período. Na tradição cristã, Cristo não é representado como ele foi crucificado, pois essa punição, aplicada em geral a escravos fugidos e a rebeldes políticos das províncias, exigia que o condenado ficasse nu, os pregos eram enfiados entre os ossos dos antebraços (se postos na mão o corpo despencaria) e ele não carregava a cruz toda pelas ruas, mas apenas a barra horizontal (a vertical já estava colocada no local habitual). Na pintura católica, o manto da Virgem Maria tem sempre a mesma cor, o pintor não pode inventar.

A tradição da arte sacra é, portanto, de imposição de regras aos artesãos, sem que estes tenham liberdade de fazer grandes inovações. Só no final do século XVIII surge, com Kant, a proposição de que o artista exerce a ideia de liberdade ao criar, ele deveria imitar os procedimentos criativos da natureza e não apenas copiar dados dela. Só nessa época aparece também a noção de que a liberdade é o que caracteriza, ou deveria caracterizar, o ser humano. Em comédias de Aristófanes questiona-se se o escravo realmente teria alma: mesmo que tivesse, não teria dinheiro para pagar o barqueiro que levaria sua "alma" para os Campos Elísios. Cada família da aristocracia via-se como descendente de algum deus ou deusa, de maneira que os membros dela eram "contaminados" pela superioridade e imortalidade divina. Disso estava longe a noção de que os homens seriam iguais.

A liberdade pode estar fora dessas três linhas hermenêuticas, refugiando-se numa esfera pouco frequentada em seu adensamento crítico e teórico: a teoria literária. Não essa que se pratica no Brasil, como propedêutica ao estudo do cânone literário nacional, mas outra, que não é uma escola nem uma corrente, aquela que tem ali e acolá um ocasional representante - como Blanchot, Peter Szondi, Paul de Man, Beda
Allemann, Jacques Derrida -, uma espécie rara de planta, pouca cultivada. Não basta fazer estudos sobre poetas herméticos para chegar a ela: é preciso estender o fio entre duas montanhas, o diálogo no ar rarefeito, enregelado e perigoso.

Nietzsche e Heidegger são, entre os filósofos recentes (Platão e Pascal, por exemplo, foram grandes escritores), aqueles que mais se aproximaram do diálogo entre poesia e filosofia, mas acabaram instituindo novos "pré-conceitos", como achar que a linguagem é a casa do ser ou que a verdade como "alétheia" seja uma clareira. A verdade de uma floresta não é, em geral, a clareira e sim a mata densa, cerrada. As matas europeias costumam ser mais claras do que a mata atlântica ou a amazônica: pode-se caminhar por dentro delas, até cavalgar, pois em geral elas não são feitas de várias camadas verticais de vegetação, não tem cipós nem arbustos internos, mas não é disso que Heidegger fala.

Celan contrapõe a essa noção de clareira (daí luz, iluminação) a noção de obscuridade: "diz a verdade quem sombras diz". Entendida como "alétheia", o desvelamento que se tem no processo de conhecimento envolve um mostrar-se da coisa, mas ocultando no que se mostra tudo aquilo que dela e nela não é mostrado, sendo o próprio mostrar-se também já um ofuscamento luminoso de tal modo que só se vê o que é iluminado, do modo como é iluminado, e não a totalidade da coisa. Não perceber que não se percebe, não perceber o não percebido, é um modo de cegueira sob a aparência de estar vendo.

Heidegger chamou a linguagem de "casa do ser", o que tem sido repetido sem pensar. A língua em que nos movemos não é uma "casa": se fosse, ela seria uma prisão domiciliar, que é mais ou menos o modo como todos nós vivemos, de casa para o trabalho e do trabalho para casa. Ela é antes um campo de concentração, cheio de normas e de guardas. Se cairmos fora do parâmetro dito culto, se violarmos a sagrada gramática da norma culta, seremos automaticamente incultos e sem nada a dizer no âmbito acadêmico.

A gente se acostuma até a um campo de concentração, interiorizando de tal modo suas regras que se acaba achando que está livre. A língua é uma prisão, como produto da tradição dominante: é preciso falar como a oligarquia para ser levado a sério na ciência, na arte, no ensino. A linguagem enquanto energia criativa, que pode gerar línguas, pode ser uma abertura para a liberdade, para um dizer outro que não o previsto pelo sistema vigente. 
O governo Temer propôs que no ensino médio existiriam apenas três disciplinas obrigatórias (o que é uma redundância, pois toda disciplina obriga): matemática, português e inglês. Por que e para que essas três e não outras, o que tem elas em comum? Quando aí se fala em "matemática" não se está discutindo fundamentos matemáticos e sim o treinamento das mentes dentro de uma lógica formal, em que se aparenta estar sendo exato ao fingir que o semelhante é igual, podendo-se descartar as dessemelhanças no semelhante, ou seja, eliminando-as como se não existissem e não tivessem a validade do diferente, da minoria, do dissidente.

Quando se fala em "língua portuguesa" não se está falando em estudo histórico da diversidade dos falares de uma suposta língua portuguesa, mas em gramática normativa, imposição da norma supostamente culta, da suposta fala da classe alta do país, em detrimento dos falares regionais, da fala dita inculta, da expressão das camadas mais pobres da população, das diversas línguas faladas no território do país. Novamente uma imposição de classe interna. Quanto ao ensino do inglês, não se trata simplesmente de dar acesso a uma língua de trânsito internacional, uma espécie de latim do século $X X$, mas de uma submissão colonial ao império americano e inglês.

A língua inglesa nem é, sequer, de um ponto de vista linguístico, a melhor língua de trânsito internacional, a começar pelo fato de se ter de aprender duas línguas em uma: a escrita e a falada, que pouco tem a ver uma com a outra. O espanhol não tem essa dificuldade, o que se escreve se fala, para cada grafema há um fonema e para cada fonema um grafema, em número reduzido a um mínimo, sendo já uma língua falada por uns 600 milhões de pessoas. Tem-se, portanto, a pretexto de uma necessária reforma do ensino, uma imposição ideológica de direita, de cima para baixo, em que a escola se torna um picadeiro de domesticação.

Estamos longe dessas questões quando, em noite sem lua e sem nuvens, nos deitamos de barriga para cima e contemplamos a solidão dos espaços siderais. Podemos perceber que não percebemos a maior parte do que haveria a perceber. Bobagem, portanto, reduzir tudo o que há, o havente, ao rol mínimo das coisas de que temos alguma noção e que chamamos de entes, aquelas que nos aparecem e às quais damos um nome. Não se precisa fazer do obscuro uma profissão de fé: ele tem sido reiteradamente mostrado pela ciência e pela tecnologia, mas ele também é tema de um número limitado de poetas e pensadores. De algum modo, grandes obras de poesia e filosofia falam desse obscuro, sugerem mais do que dizem, dão a entender mais do que podem dizer. É preciso ver se grandes obras de arquitetura ou música podem alcançar tão bem ou melhor essa transcendentalidade.

Será que a noção do "Seyn", da transcendência do que fica fora do âmbito da nossa percepção e dos nossos conceitos, não pode se dar melhor por outras linguagens que não as da palavra, seja ela poética ou filosófica? A Catedral da Sagrada Família em Barcelona, projetada por Gaudí, pretende ser um monumento à família formada por José, Maria e o menino Jesus. Pelo que conta o Evangelho de Maria, considerado apócrifo pela Igreja Católica, mas que é mais plausível do que o conto de carochinha dos Evangelistas, Maria, que era uma virgem do templo em Jerusalém, foi engravidada pelo sumo sacerdote Zacarias, que emudece por um ano para não ser questionado, mas promete ajuda ao filho e ameaça José, obrigando-o a obedecer.

Qual é a santidade dessa família? A esposa engana o marido, engravida de outro e é, portanto, infiel. Assim sendo, o marido é, em brasilês, um corno e, a essa altura do campeonato, o menino é um filho da mãe. De "santa", essa família não tem nada. O que é "sagrado" representa um valor mais elevado e deve, portanto, ser seguido e imitado. Será que os maridos catalães e espanhóis estão dispostos a catar amantes para suas esposas poderem engravidar?

Há uma contradição entre o fático e o idealizado, gerando uma fresta para o abismo e a infinitude. Isso transluz pelos vitrais e paira na atmosfera interna da catedral. A mitologia católica serviu a Gaudí para sugerir algo que ele povoava com seus deuses e seus santos, mas que significam algo muito além deles. É preciso resgatar da obra de culto a obra de arte. $\mathrm{Na}$ estrutura em pedra se esconde algo que não tem palavras, pois não precisa delas para se dizer.

Para Hegel, a linguagem da arquitetura é grosseira e simplória, incapaz de chegar aos píncaros da poesia e necessitando desta para ser entendida. As pirâmides do Egito, para ele, não sabem dizer bem a que vieram. Talvez essa leitura seja simplória. Elas representavam a estrutura hierárquica da sociedade egípcia e se destinavam à preservação de uma pessoa, que era vista como um deus. O formato da pirâmide sobe do chão para o alto, do largo para o topo estreito e, lá em cima, fora da visão, no espaço azul, alça uma nova pirâmide invertida, feita de nada, que se abre para a infinitude. Isso é maior do que as crenças religiosas e políticas egípcias.

Gaudí era muito católico e parecia acreditar no conto de carochinha. Tratou de convencer outros a ajudá-lo na empreitada: ergueu um grande monumento a um erro primário de compreensão, à conversão do pecado em virtude. Ele era inteligente mais que o bastante para 
perceber que havia um problema na diferença entre o que provavelmente se passara e o que se pretendia transmitir. Ele quis transmitir essa sensação de sublime, de transcendentalidade, de mistério: e é isso o que paira no ar dentro dessa catedral, com o efeito que os vitrais provocam, algo que vai se modificando conforme a luminosidade externa. Tendo outro espectro, nenhuma obra de Niemeyer alcança o nível dessa obra de Gaudí.

É algo semelhante ao que provocam os maravilhosos vitrais da catedral de Chartres, na qual se procurou trazer a transcendência para perto dos "fiéis", com a concepção de que Deus seria luz. Esta deriva de um erro de tradução. No livro VI da República, Platão diz que não basta uma coisa a ser vista e um olho a ver para que ocorra a visão: é preciso que haja luz, condição de possibilidade da visão (não passava pela cabeça dele supor que seria preciso haver nervo ótico, neurônios treinados e que algo semelhante ocorre em todos os sentidos). Chamou de "ágathon" a essa condição possibilitadora, termo que foi traduzido por "Sumo Bem" no final da Idade Média, ou seja, Deus como condição de possibilidade de tudo.

Na universidade de Yale, em New Haven, existe uma biblioteca de livros raros, a Beinecke Library (que aparece no melhor romance de Humberto Eco, O nome da rosa). As paredes dela são de mármore colorido cortado tão fino que permite a luz passar por ele. Conforme andam as nuvens no céu, muda-se a ambiência da biblioteca, gerando uma atmosfera de encanto e maravilhamento, como a dos grandes livros, aqueles que merecem ser preservados.

Essas três obras arquitetônicas têm algo em comum, essa atmosfera do sublime, da transcendentalidade que aparece ao homem e que não é entendida propriamente por quem vê apenas um prédio de culto religioso ou um depósito de livros velhos. Elas podem acenar e encenar melhor uma transcendentalidade laica do que um poema ou um tratado de filosofia. Portanto, não apenas a palavra é a instância privilegiada do espírito, mas também a pedra, o vidro, a tinta.

A mais famosa obra de Picasso é Guernica, que costuma ser apreciada como protesto contra o bombardeio da cidadezinha do mesmo nome durante a Guerra Civil por aviões militares alemães. Ela não podia ser apreciada na Espanha durante o fascismo de Franco, pois era uma condenação dele. Foi depois posta no Museu Rainha Sofia, cercada de obras e cartazes de protesto surgidos durante essa guerra, que ajudam a localizar a obra num tempo e lugar, como se fosse um testemunho dele. Esse é o modo como habitualmente se constroem as histórias da arte, que reduzem as obras a um documento cronotópico. O despedaçamento de corpos humanos e cabeças de touro protestam, porém, contra mais do que um momento numa vila. Eventos semelhantes aconteceram em muitos outros anos e lugares. Como arte, a obra é, porém, mais que isso.

Um modo de se aproximar de uma grande obra é vê-la acompanhada por outras obras, para verificar, por semelhança e por contraste, o que a diferencia. Ou seja, diante do ser da obra delineia-se o espectro do seu não ser, aquilo que ela poderia ter sido e não foi. Ela é o que é por não ser o que não é. Isso não significa que ela esteja errada por não ser como não é, embora isso aconteça na maioria dos casos. Na grande obra desvela-se que ela poderia ter sido outra, mas deveria ter sido como é, para melhor sugerir aquilo que com ela se pretendia. Embora nela também se mostrem alternativas, elas acabam sendo modos diferenciados de lê-la e interpretá-la que exibem com nuances o seu perfil próprio, insubstituível.

Isso significa, por exemplo, que a obra pode ser bem diferente da intenção consciente do autor ou que o receptor não tem as mesmas crenças ou posições políticas refletidas na obra, de tal maneira que não seria mais possível fazê-la aqui e agora do mesmo modo como foi feita, o que leva a uma releitura, para ver onde se abala o paradigma proposto pela obra, pela tradição e pela fortuna crítica. Disso resulta, a partir do mesmo artefato, outra obra, diferente da original. Se 0 artefato conseguir sustentar uma releitura, a obra se mantém: se não, vai para a lata de lixo da história ou, ao menos, para a lata de lixo desse intérprete. O não ser ronda o tempo todo o ser da obra.

Diversificar as fontes de referência, jogar erudição em detalhes da obra e de sua interpretação, confrontar obras e mais obras, tudo isso leva a uma poliontificação, mas não necessariamente à ontologia. É preciso ter o olhar agudo que perceba no detalhe a corporificação do mais amplo e que capte as macroestruturas da obra. Sem esse jogo contínuo não se capta o que realmente importa.

Há obras teóricas e artísticas muito boas que nem aparecem para o público, não encontram espaço na mídia ou nos museus. As que aparecem podem não aparecer pelos melhores motivos, ainda que não sejam os delas: são sustentada por ideologias, não por sua verdade. Nas obras que aparecem desaparecem as que não aparecem. No que aparece há um não ser que finge ser. Está-se tomado pelo nada, é-se governado por ele, sem saber. Ignora-se o nada que nos toma. O próprio Deus é um nada que parece tudo a quem nele crê. 
Quando se examinam questões de epistemologia, ética, política ou estética, só se fica na superfície delas quando não se examinam seus fundamentos metafísicos. Pior é que não se pode confiar nas respostas dadas pela tradição metafísica. Só desconfiando delas é possível, portanto, avançar no território sombrio e ignoto que caracteriza a sua busca. Não se pode confiar nos grandes autores e menos ainda nos seus diluidores. Resta saber se há uma trilha em que se pode andar nessa floresta. Parece que sim: na grande poesia hermética.

O próprio Heidegger sentiu essa trilha, examinou alguns poemas de alguns poetas herméticos de língua alemã Hölderlin, Trakl, Rilke, Stephan George -, tendendo a converter o que havia neles ao horizonte do seu próprio pensamento. Essa é uma trilha ôntica, germânica, que pretende ser ontológica. Beda Allemann fez ótima tese de doutorado, conforme reconhecido pelo próprio Heidegger, confrontando o pensamento deste com a poesia de Hoelderlin: por mais pertinente que fosse essa tese, ela não tinha a pretensão de ir mais longe que suas duas referências, embora discernisse seus horizontes, mas era uma trilha a ser seguida, um tipo de teoria literária como não se costuma ver. Já por uma questão de cronologia, é, no entanto, na obra de Paul Celan que se vai encontrar uma resposta poética a Nietzsche e Heidegger, a ponto de se suscitar a tese de que seria uma página virada adiante, um novo capítulo.

Embora Heidegger conhecesse bem diversas línguas grego, latim, francês, alemão - uma limitação dele é que restringiu suas reflexões ao horizonte da poesia de língua alemã, quando poderia ter encontrado uma ampliação em obras como os sonetos de Shakespeare, os poemas de Baudelaire e Mallarmé, de Mandelstam e Fernando Pessoa, não por acaso traduzidos para o alemão por Stephan George e Celan, que deviam estar sondando suas inquietações neles. Para o que ele queria sugerir quanto ao "Seyn", arquitetura e música sinfônica poderiam ser estratégicas. Entre os poetas de língua alemã, podem-se tomar alguns tópicos de Celan, ver neles respostas implícitas a posições de Heidegger. Isso não significa que o poeta seja uma superação do pensador, no sentido de sua invalidação. Pelo contrário, o diálogo implícito permite que se delineie a grandeza do embate.

Se o embate principal se dá, porém, com Hoelderlin, acaba tendo as peculiaridades deste, cuja formação helenística, sob o espectro da ideologia aristocrática e apolínea, Ihe fazia ter saudades da Grécia antiga. Tinha saudades dos deuses antigos, em vez de sentir horror à superstição e legitimação do escravismo que representavam. Não seria um dia de festa se eles voltassem a conviver com os homens, eles não são uma boa alternativa à mitologia cristã, com todos os seus absurdos. Serviam, isso sim, para entender o cristianismo como uma mitologia entre outras, não para convocar um retorno reacionário ao pré-cristão. Como o coração posto em bandagens procura abrigo no lar da infância, este só reaparece como fantasia, e sempre melhor do que realmente foi.

Dos heideggerianos não se pode esperar que aceitem tal superação: eles ficam no horizonte do proposto por seu mestre. Tendem a não tomar conhecimento de alternativas. Na mentalidade colonizada que ainda impera no Brasil, quem pode trata de se filiar a um mestre de prestígio, passando o resto da vida a fazer notas de rodapé a detalhes de sua obra, mas fazendo de conta que está dizendo o essencial, pois, afinal, é o dono dele. A teologia católica forma o inconsciente da filosofia no Brasil. Esta era ensinada em geral por antigos seminaristas e padres, que, talvez sem querer, tendiam a reduzir o horizonte do questionamento metafísico ao palatável à religião.

Não adianta se deixar intimidar pela perspectiva desses "entendidos". É preciso ousar seguir o curso de um diálogo interrompido entre as artes e a metafísica. Não se pode restringir o diálogo à palavra, para pela poesia privilegiar a filosofia. As outras artes não entram nesse diálogo, alegando-se sua incapacidade de veicular pensamentos complexos e densos. Essa concepção é limitada. A música pode ter dificuldades de dizer com clareza conceitual a que veio, mas o que se verifica com o conceito é sua natureza finitizante, sua incapacidade de se abrir para o transcendental, mesmo que não se trata de um poeta qualquer. Quando se fala em Rilke, é preciso lembrar Auguste Rodin; quando em Celan, Brancusi. Há na poesia um diálogo implícito com outras artes, uma abertura que o conceito não deve interditar.

\section{Etapas a desenvolver}

Há várias etapas a percorrer: 1) absorver os clássicos da filosofia e da arte europeia; 2) refletir sobre suas limitações; 3 ) dar um passo adiante. Não é possível chegar ao terceiro sem passar pelos dois primeiros. Entre os profissionais das áreas técnicas e humanas, são raros os companheiros de jornada: eles ficam mergulhados no ôntico de sua área, dominados pela tecnologia que supõem dominar e não são capazes de dar o primeiro passo. 0 segundo passo é difícil, pois é preciso captar as estruturas básicas do pensamento, para vislumbrar o que ficou de fora ou não está bem proposto. Não se pode esperar que os grandes nomes das metrópoles europeias ou norte-americanas reconheçam a validade do que se faz na América do Sul. Isso não é apenas arrogância, mas eles simplesmente não têm 
acesso a línguas como português e espanhol: os que tem não costumam ser os melhores quadros teóricos. O terceiro passo é o mais difícil: seria propor algo novo no plano mundial, com consistência teórica e capacidade judicativa, a produção de uma arte que não se filiasse a autores ou correntes consagrados nas metrópoles. Isso é optar pelo silêncio.

Escrever em português ainda é a morte do pensamento. Finge-se que se está vivo, mas podendose contar com o fato de que não se será contado nem cotado no âmbito do pensamento mundial. Essa morte é a liberdade do zumbi. Deveria permitir atuar de modo mais autônomo, mas a mente colonizada acha que se civiliza imitando o estereótipo da metrópole. Como as universidades no Brasil são recentes, nelas não se concentraram ainda os valores acadêmicos vigentes nos centros tradicionais. Isso convida à facilitação, obriga a uma dupla vigilância. Não se pode tomar o próprio meio em que se está como referência.

Até hoje, parecem ter sido a tragédia clássica e a poesia hermética moderna europeia que conseguiram travar um diálogo com o mais avançado do pensamento de sua época. Isso precisa ser revisto, mas não à base da valorização da cor local. O que significa a obra de um Picasso como reflexão filosófica? Não se está aqui pensando na "Mulher que chora" como algo biográfico de uma das esposas nem na "Guernica" apenas como protesto contra massacres na guerra civil. Seres vivos reduzidos em pedações, reduzidos a fragmentos, são uma avaliação da história. Há algo mais, indiciado, por exemplo, pelo cubismo, com sua redução do mundo a formas geométricas elementares como um modo de ver as coisas.

Quando se está numa Faculdade de Arquitetura em que se ignora a Metafísica, não se tem o estudo sistemático de Arquitetura Comparada, da Arquitetura Oriental nem de Crítica Arquitetônica, como supor que se vá chegar a um horizonte que nem é levado em conta? O que seria da arquitetura se ela fosse vista pelo avesso, não como construção de paredes e tetos, mas a elaboração de vazios, de nadas? Isso parece piada metodológica, mas aponta uma questão ontológica. A arquitetura precisa se redescobrir como arte, não supor mais que imitar a Bauhaus seja a arte suprema, para daí se pensar como metafísica em pedra. Ninguém parece querer esse abismo. O que se quer são pontes, não buracos negros em que se possa cair, casas como abrigos contra o nada, não o nada como constitutivo dos seus vazios.

Que a teoria literária brasileira não esteja à altura desse diálogo, ignorando-o, é um fato, mas ela não é o único horizonte possível dessa questão, como também não é ver outros professores se angustiaram para apresentar a última moda da Rive Gauche ou do Quartier Latin e deixarem todos deslumbrados. Como se vê, estamos tergiversando, para não ter de enfrentar a difícil questão "metafísica e arte". O que se aponta para nós, como alternativa, é uma tradição formada por alguns pensadores e poetas que preferiram ser chamados de "obscuros", porque faziam da obscuridade "profissão de fé", como Pascal, Fichte, Schelling e os grandes poetas herméticos. É preciso ir, porém, mais longe, sondando obras em outras linguagens que não a verbal, esta sim, um preconceito teológico que domina a filosofia. Não se trata de um convite ao misticismo nem ao esoterismo.

Há o ignoto, que a todos ronda, escondido no pavoroso silêncio dos espaços siderais, mas também no inconsciente de cada um, na inquietação política, na imprevisibilidade do amanhã, na morte latente que late na escuridão. Finge-se que tudo isso não existe, mas fingir não faz não existir. O reprimido retorna, com mais força do que se tivesse sido pensado. Pensar e falar muitas vezes não resolve nada. A consciência finge que pode controlar aquilo de que ela fala, mas fracassa diante do inexorável. Em três milhões de anos, no máximo, não vai mais haver ar na Terra. Países com porta-aviões e mísseis atômicos intimidam quem não os tiver. O nada late na escuridão.

Como entender a "profissão de fé" no obscuro se exatamente se quer superar o obscurantismo da fé? Talvez seja uma "aposta", o prenúncio de que há certa direção para onde ir, como fazer, como perquirir, sem que se tenha antecipada a certeza de um resultado. Não há cronograma nem objetivos específicos para isso. Não há uma "conclusão" a apresentar no fim, não há sequer propriamente um fim. Há um percurso. Um prenúncio talvez, já enunciado por alguns pensadores e poetas. Um caminho que se faz ao caminhar, mas que desfaz inúmeros outros caminhos possíveis. Todo caminho é a negação de outros caminhos. Nem todos que entram por essas veredas chegam ao outro lado, aliás, talvez ninguém chegue, não há saída, outro lado. Há inúmeros outros lados.

A razão, para ter ainda razão, precisa admitir o inconsciente do sujeito. Agora precisa admitir o inconsciente das coisas, não no sentido de que elas não têm consciência (talvez tenham, sendo a força da gravidade uma amostra disso), mas no sentido de admitir o ignoto que reside no que se parece conhecer. Não apenas o coração tem razões que a razão desconhece. Tudo o que fica fora do sujeito também. 
Não basta dar uma lida em textos de Heidegger sobre poetas alemães seletos: eles não são o único horizonte da poesia. Quando ele usa expressões que se tornaram consagradas como "Dasein", a "língua como casa do ser", a "clareira" como lugar da verdade enquanto desvelamento, é preciso desconfiar desse sucesso. Talvez estejam erradas. A verdade de uma floresta não é sua clareira: nesta se tem o que seria "claro e distinto", dentro do paradigma proposto por Descartes. Com esse tipo de proposição se está preso ao pensamento moderno, não dando a volta por cima.

Se a matemática finge que é igual o que é apenas semelhante, descartando o dessemelhante como se fosse irrelevante, ela não é tão "exata": os traços de um pintor ou as notas de um compositor e as palavras de um poeta precisam ser muito mais "exatos" que as "ciências exatas". Como o "ser humano" seria o único "Dasein", se tudo o que há está também por aí? O homem não é tão importante, exceto para o seu narcisismo: a metafísica especial se divide em cosmologia e psicologia, além da teologia, como se o homem fosse um equivalente ao "universo" inteiro, como se ele fosse um "cosmos". Não se viu aí a teologia como uma parte da psicologia: institui-se a alienação, sem consciência crítica de si.

Toda grande obra tem a sua negação em si mesma, ela presentifica uma ausência, traz para perto algo distante, que fica nela como ausência presentificada, como uma alternativa que ela preferia acenar a realizar. Essa outra obra na obra, uma espécie de antissistema em seu sistema dominante, não é mera invenção do intérprete, mas um potencial de leitura, necessário para entender a opção feita pelo autor.

\section{Celan}

Celan não é poeta sobre o qual Heidegger tenha escrito, embora ambos se conhecessem. $O$ ponto de partida poético dele se encontra em Hölderlin, Rilke, Trakl e Stephan George, poetas caros ao filósofo, mas também na poesia francesa e russa. Ele traduziu Fernando Pessoa, sem conhecer bem português. Há, portanto, em sua obra poética um diálogo com a mesma sequência de grandes poetas alemães, bem como um diálogo com um filósofo como Nietzsche, que dizia que a Arte é o que torna a vida suportável.

Hölderlin escreveu uma tragédia inconclusa sobre Empédocles, o filósofo que, querendo superar o abismo entre as coisas e a consciência humana, jogou-se no Etna (dizem as más línguas que o vulcão vomitou uma sandália dele). Torna-se um percurso próximo à morte adiada não se fixar em nenhum dos mundos, laborar suas diferenças e contradições, buscar a superação da estreita história que se vive, trabalhando a palavra antes de jogar-se no nada:

\author{
BEBO VINHO de dois cálices \\ e lavro \\ na cesura real \\ como Aquele \\ no Píndaro, \\ como um desses ínfimos \\ justos, \\ Deus depõe o diapasão, \\ da roda da sorte cai \\ nosso tostão. ${ }^{4}$
}

Se Deus fosse justo, deveria depor o diapasão, o instrumento com que se pretende impor harmonia às coisas humanas. O homem, um ser ironicamente definido por Heidegger como um estar aí para a morte, pode ter na morte a opção de liberdade que a vida não Ihe deu, diante de uma história que é um desfile de crimes coletivos e de uma existência em que "não se morre a morte cor de malva". Nesse percurso da paixão, as pedras traçam a trilha da morte, os livros são as paradas de uma reflexão a caminho do Calvário, sem que, com isso, se faça do poeta um Cristo que, como um cordeiro, se sacrifica pela coletividade e ressuscita glorioso na edição crítica e em celebrações diversas. Celan não era cristão para acreditar nisso, mas entendeu o poema como um anjo, um mensageiro da história, um presente doado aos pósteros. Esse presente ajuda-os a sobreviver, como se fosse essa a intenção do poema, que é, assim, traído:

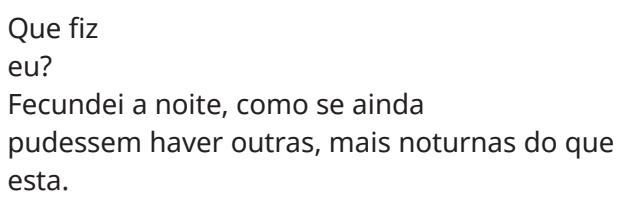

O dia da história iluminada é uma longa noite, maior ainda para quem não a percebe. Quem se conforma com tudo, aceita tudo, não vive por nada, já vive no nada, está morto e não sabe: se aceita tudo, não vale nada. A literatura é um espaço que pode perguntar-se por isso, com mais liberdade do que outras linguagens, ainda que, para ser transformada em cânone, tenha de formular um discurso em que as respostas prontas se tornam a récita de um catecismo. O cânone se impõe, a poesia apenas se expõe. Por isso, a grande poesia está à margem do cânone, não tem necessariamente nada $a$ ver com a sua imposição institucional.

${ }^{4}$ Kothe, Flávio R. A poesia hermética de Paul Celan, Brasília, Edunb, 2016, os poemas citados se encontram nesse livro. 
A poesia hermética estabelece um diálogo com a tradição e guarda comentários que não se dão na linguagem prosaica dos filósofos. Quando Celan escreve, por exemplo:

EM VÃO traças corações na janela:

o duque do silêncio

conclama soldados no pátio do castelo.

Aí ele está reelaborando um poema de Goethe, de 1827, do Divã Ocidente-Oriente, que começa dizendo que "poemas são janelas pintadas", como quando se fazem desenhos numa janela embaçada e assim se vê uma paisagem além. Embora o autor não fosse crente, ele critica aí quem não compreender o fiel que vai para o seu templo. Celan cita aí também um poema de Rilke, conhecido como "Cornett" (Die Weise von Liebe und Tod des Cornets Christoph Rilke), em que se fala de um jovem que, no mesmo dia, conhece o amor e morre numa batalha.

Muitos poemas dele são a reelaboração de Nietzsche, especialmente de fragmentos do espólio. Baseado no livro $A$ evolução das espécies, de Darwin, o filósofo propôs que o homem histórico deveria servir como um mármore para esculpir um ser melhor, um ser acima do humano. Celan não tem o otimismo forçado, de crer que isso venha a ser possível. Crê antes no "eterno retorno do mesmo". Ele precisa ser lido de trás para a frente, a partir da sua morte voluntária, não como um ato de súbita loucura, mas de cuidadosa avaliação da história, para dizer que a existência do que se tem chamado de ser "humano" não merece a qualificação que o termo propõe.

Há uma ambiguidade exemplar em um poema que foi objeto de longas pesquisas na Alemanha, para verificar o que o autor tinha em mente ao escrever:

\author{
FIAPOSSÓIS \\ sobre o grisnegro ermo. \\ Um pensamento \\ alto como árvore \\ se agarra ao tom da luz: ainda \\ há canções a cantar além dos \\ homens.
}

O sol significa, ao menos desde os egípcios, o centro de referência, a divindade que norteia e determina tudo. Esse sol se despedaçou, restam apenas fiapos, sóis esfiapados. Eles podem percorrer o ermo de uma floresta, como uma paisagem ausente de homens. Há uma desconstrução da metáfora: o pensamento tenta se agarrar às tonalidades da luz, para se tornar elevado como uma árvore, passando do visual ao auditivo. Ele quer propor uma esperança, desconfiado de que ela não seja mais possível.
O que significa essa conclusão: "ainda/ há canções a cantar além dos/ homens"? Significa: 1) além de cantar os homens, ainda há outras canções a cantar; 2) as canções a serem cantadas estão além dos homens; 3) por enquanto, provisoriamente, ainda há canções a cantar. Quer dizer tudo isso, e quer dizer algo mais, que é tudo isso, e, no espaço de suas contradições e exclusões - em que o mais importante é o espaço que se abre além da humanidade que já existiu - outro sentido, que não é redutível a nenhum desses argumentos lógicos e que é o espaço próprio, peculiar do poema.

\section{Esse texto aparece pouco após o poema: \\ NOS RIOS ao norte do futuro \\ lanço a rede, que tu \\ indeciso lastras \\ com por pedras escritas \\ sombras.}

Esse "tu" pode ser um modo de o autor referir-se, de fora para dentro, a si mesmo, como que a sondá-lo por que ele fica lastrando o futuro com sombras escritas por pedras. Essas pedras podem ser lápides mortuárias, dos familiares perdidos em perseguições e tantos outros mortos em guerras. A rede é um texto, como o poema, e serve para captar peixes, sentidos, nos seus vazios. As pedras permitem à rede mergulhar e pegar o peixe da ideia que inquieta se move no subconsciente.

O que significa "com sombras escritas por pedras"? Quer dizer que as pedras projetam sombras, as pedras são sombras que dão lastro à rede ou que as sombras são projetadas pelo sujeito nas pedras? O que significa "que tu indeciso lastras"? Quer dizer que tu, porque és indeciso, impões um lastro, ou que, ante as sombras escritas por pedras, tu ficas indeciso? Ou significa, toda vez, algo mais, diferente de cada uma das versões e que está além delas? Compor pedras escritas: sombras.

Lido de trás para frente, o dilema se resolve, o sujeito já não está mais indeciso. Já não significa mais que, além de cantar os homens, ainda há canções a cantar, mas que as canções a serem cantadas são aquelas que estão além dos homens e que, sendo humanas todas as canções, até mesmo aquelas que reneguem o homem e a sua história, nenhuma canção mais deve ser cantada pelo sujeito: a vitória final é do silêncio que a todos se impõe. Qualquer palavra dita é uma concessão demasiada. É o silêncio que fala na "selvagem convicção/ de que isso também pode ser dito de outro modo" (II, 201). Só merecem ser ouvidas as canções das sereias, que convidam os marinheiros a mergulharem para sempre no fundo das águas, abandonando todo o esforço e percurso civilizatório. 
Heidegger ficou numa "inocente" visão do homem como "sein zum Tode", sem ver que há muita morte em vida, aniquilamento das melhores possibilidades, guerras civis, genocídios. Celan escreveu o mais famoso poema em língua alemã do pós-guerra, a "Fuga da morte", que se tornou central para a elaboração da culpa pelo holocausto:

\section{Ele grita toquem a morte mais suave a morte é um mestre da Alemanha \\ ele grita toquem os violinos mais grave e elevem-se qual fumaça pelo ar \\ então vocês terão uma cova nas nuvens lá não se fica confinado;}

Esse poema foi retomado em outro, o seu poema mais longo, "Stretto", que também usa a forma da música: o stretto é a parte da fuga em que os diferentes temas e variações são novamente reunidos, rapidamente, antes do final:

LEVADO ao
campo
com a marca fatal.

Relva, soletrada. As pedras, brancas, com as sombras dos caules:

Não leias mais — olha!

Não olhes mais — vai!

Esse poema, que tem sido lido como um rememoração de Auschwitz, enquanto emblemático afloramento do Anti-Messias, foi escrito por Celan, conforme ele mesmo fez questão de lembrar, pensando nas vítimas da bomba de Hiroshima:

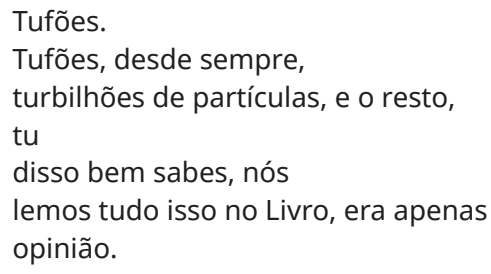

Se o fato subjacente não era Auschwitz, mas basicamente Hiroshima, era também Nagasaki, o Inferno de Dresden, os bombardeios do Vietnã, os conflitos étnicos na ex-Iugoslávia, as matanças na África e tantos outros momentos de destruição, perversidade, aniquilamento.

A grande poesia é perigosa. Ela se dá à beira-abismo. Não se é Poeta por escolha, mas por condenação, tomado e arrastado por forças que são mais fortes, que ele preferiria ver longe de si, mas que se embatem em sua interioridade. Uma sensibilidade à flor da pele não tem condições de proteger o espírito dos embates cruéis da maldade inerente ao funcionamento da sociedade.

\author{
O MUNDO, i-mundo, \\ justo em toda a sua imundície, \\ e eu, eu, \\ junto a ti, a ti, estig- \\ matizado.
}

O mundo é imundo, é um não-mundo, mas aparece como justo, correto, justificado em toda a sua imundície: a imundície não aparece como tal, e sim como justiça, mediante a justificação do existente: quem é diferente da concordância, quem questiona e discorda, fica estigmatizado, mas, no estigma, ele encontra também um matiz que lhe permite ver, com a lente de aumento da lágrima, o que outros não querem ver. Fica, no entanto, marcado, martirizado. Assim como a palavra corrente lhe serve de luz na busca, ela serve comumente para esconder a verdade, tornandose a casa do não-ser.

É ambígua a sua vocação de ser "escuridão-limiar e beira do obscuro" (II, 177): tanto pode gerar a obscuridão quanto pode ser sua devassa. Mas quem garante que a luz não está na escuridão, assim como oculta sua verdade aquilo que aparece iluminado como palavra pública? O eu, que tem essa percepção avessa à ideologia dominante e que não se ajoelha diante dos deuses propostos como ídolos, aquele que tem outros valores dentro de si, esse fica estigmatizado e, logo, martirizado: a marca do estigma cria-lhe, porém, uma nuance, um matiz, que o diferencia da matriz dominante, mas que quase não lhe permite existir, tanto que precisa reafirmar mais de uma vez o seu eu, como se dele duvidasse, e mais de uma vez o tu, com quem ele pode ainda se encontrar, pois também fica marcado pela solidariedade com a sua diferença.

O poema é uma tentativa de não deixar-se naufragar. É o contracanto ao canto e encanto da sereia, que acena o retorno à natureza, o mergulho no olvido da consciência. Ser Poeta e fazer/publicar versos não são sinônimos. O Poeta tende ao silêncio, enquanto o fazedor de versos tende ao palavrório.

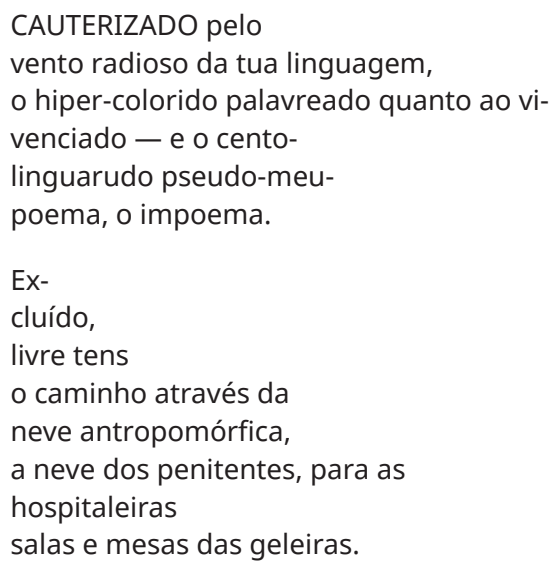


Fundo

na fenda dos tempos,

nos

favos de gelo,

aguarda e espera,

como um sopro cristalizado,

teu incontestável

testemunho.

Esse poema é uma reelaboração de textos de Nietzsche, mas também do que Heidegger chamou de "Gerede", a conversa fiada, o blablablá, que domina o cotidiano. Ela é caracterizada logo no início, como a fala que não se poderia ter. Ela é o não-ser da conversação, um vazio que ocupa muito espaço.

O poema é montado numa sucessão dialética: a primeira estrofe, a tese, caracteriza o poema corrente, linguarudo, existencial, caracterizado como o nãopoema, o poema como ele não o quer. A segunda estrofe constrói a antítese, o poema do perene exílio, da distância absoluta em relação a convivência próxima do mundo do palavreado: a frieza do gelo e da neve caracteriza de modo mais exato a convivência dita humana. Na terceira estrofe - nessa fase intermediária da produção - ele ainda vê um sentido para o seu trabalho, enquanto um testemunho para tempos vindouros, feito um sopro cristalizado. Mais tarde, isso já não terá mais sentido para ele. Não se trata de consumir arte para assim salvar a vida, mas manter a vida para fazer arte. Esta se carrega de negatividade, procura-se nela uma salvação que ela não pode dar.

O artista é a cabeça de Medusa que congela um momento da realidade, fazendo do horror uma fixação em palavras, pedras, cores. Ele transfigura o que aparece, dando-lhe a força do que transcende o instante. O fixado se torna um presente do presente para o futuro, um mensageiro, como mel posto em favos de gelo, a palavra que ainda foi dita, contra tudo e contra todos, um sopro cristalizado. Como isso não se reduz a um sistema unívoco de assertivas, como é o ensaio do filósofo, permite leituras diversas que vão sendo suscitadas ao longo do tempo. A palavra do poeta é mais ampla e vai mais longe que a palavra do filósofo.

A grande poesia é perigosa, pois percorre os ínvios caminhos do questionamento radical dos valores e do sentido da história e da existência. Isso é algo mais do que os versinhos de Drummond, feitos a partir da leitura de Heidegger, quando este buscava em Hölderlin um caminho para transcender os limites do pensamento conceitual:

Lutar com palavras

é a luta mais vã;

no entanto lutamos

mal rompe a manhã.
Lutar com palavras pode parecer vão, mas seguramente não era para um escritor que, tendo sido chefe de gabinete de um governo fascista, viu sempre todos os jornais e editoras abertos para suas publicações. Nesse tom, qualquer revisor de texto, qualquer escriba de repartição, qualquer jornalista pode achar que é um grande poeta. Isso está, no entanto, longe do oxímoron de Celan "a noite começa com o amanhecer", da linhagem de Hölderlin, Mallarmé, Trakl, Rilke. Celan propunha:

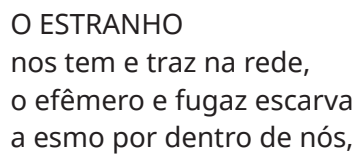

conta o meu pulso, também ele, bem para dentro de ti,

nós então nos erguemos, contra ti, contra mim,

algo nos veste e investe na pele do dia, na pele da noite, para o jogo com a mais elevada, convulsiva e epilética seriedade.

As palavras dos poetas não valem praticamente nada em nossa sociedade. Ninguém está disposto a pagar algo por elas. As palavras de um médico em uma receita, de um advogado num parecer, de um administrador num despacho - todas elas têm valor de mercado, são pagas, podem ser até bem pagas. As palavras da propaganda, dos assim chamados criadores nas agências de publicidade, daqueles que não têm um compromisso intransigente com a verdade, mas são capazes de inventar uma retórica da meia-verdade, ou da plena mentira, esses conseguem ser pagos, até bem pagos, como são bem pagos os autores de folhetins eletrônicos, em que se aparentam expor grandes conflitos (sempre, porém, em doses homeopáticas, reiteradas e diluídas, recheadas de apelos à salvação e com a garantia de darem a vitória ao bem), para doutrinar um público de nível baixo.

\section{Arte comparada}

O estudo da arte comparada ocorre em termos conceituais. Só assim ele pode se dar. A filosofia da arte tende a reduzir o artístico ao conceito. $O$ ensaio teórico, diferente do ensaio em música, é conceitual. Seu substrato não é, porém, apenas conceitual. Ele se alimenta de dados práticos e relatos históricos, mas seu fundamento maior está na vivência de obras de arte. É aí que encontra terreno sólido sobre o qual pode construir sua edificação. Isso não se transmite plenamente, porém, por conceitos. Só o leitor que tiver vivências similares poderá entender o que por conceitos se 
procura transmitir. 0 fundamento do conceito está no não conceitual e, ao examinar a arte, deve levar ao supra conceitual.

Há duas linhas subterrâneas na comparatística: uma diz que se deve trabalhar só com o que se pode descrever mediante dados e conceitos; a outra sugere que todo esforço comparativo deve servir de trampolim para que se perceba, transcendendo o conceito, a qualidade diferencial das grandes obras. Essa divisão é mais importante do que, por exemplo, entre escola francesa e norte-americana. A superação já está indiciada nelas, na medida em que a primeira se abre ao cosmopolitismo e à pluralidade cultural, enquanto a segunda se funda da comparação de similitudes entre obras. Essa "superação dialética" não se dá, como pretende a escola de Bratislava, pela soma das contribuições de ambas subsumindo a análise a uma série de conceitos e categorias a priori, e sim por algo que transcende a comparação, com uma vivência e noção diferenciada do artístico. ${ }^{5}$

A hermenêutica religiosa, seja católica ou luterana, era um modo de ditar uma compreensão aparente de passagens obscuras ou insensatas da Bíblia, substituindo o abscôndito fundamental por dogmas da fé: era um modo de controlar o entendimento, a erudição servindo para não se entender o obscuro. Ela tratava de explicar passagens ilógicas do texto bíblico, tratando de Ihe atribuir um sentido coerente, mas substituindo a linguagem figurada por um sentido literal: era incapaz de ir além do das premissas ditadas pela crença. Não ia além do cânone textual. Pretendia provar o que ela pressupunha já provado. A exegese canônica faz parte da ideologia do cânone, que acreditava ser verdade o que dizia só porque dizia.

Sua força era sua fraqueza. Mergulhada no texto, confundia verdade com crença e esquecia-se de que primeiro se precisa compreender a si mesmo, aos outros e ao mundo ao seu redor. Ficando presa a um círculo em que só valia o que ela admitia, de tanto olhar detalhes textuais tornou-se míope. Ela não sabia seus limites, pois Ihe faltava o confronto com a antítese. Mesmo que falasse em sentido literal $x$ figurado, carecia da contradição consigo mesma.

Falta-lhe: estudar a semelhança entre fenômenos culturais em diferentes linguagens, descobrir semelhanças sistêmicas em diferentes artes para compreender melhor cada uma delas, desvendar a estrutura profunda de fenômenos que condicionam a existência e afetam a cultura coletiva. Ou seja, falta-lhe o que leva da hermenêutica do hermético textual à semiótica da cultura passando pelos sistemas das artes até chegar ao ser filosófico, sem que isso deva ser confundido com imposições de uma doutrina. Assim, a exegese corrente do cânone literário brasileiro tem canonizado o já consagrado, com pequenas variações que não conseguem ver seus limites estruturais. Quando se ultrapassar a barbárie de somente estudar no Brasil o cânone brasileiro, talvez se consiga perceber a relevância de uma postura mais ampla e aberta.

É preciso desenvolver uma abordagem que passe pelos procedimentos comparativos, para poder transcendêlos. Só se poderá saber o que é o trivial tendo boa noção e vivência da arte maior. Deve-se fugir à prisão lógica do círculo hermenêutico que não saiba questionar suas premissas e crenças, para usar a via da comparação como quem caminha alternadamente sobre duas pernas ou quatro patas para poder avançar. O círculo precisa se tornar uma escadaria circular, uma espiral a buscar patamares mais elevados. Se a teoria não consegue abarcar o que, por exemplo, grandes poetas propuseram, ela precisa se esforçar, no entanto, para avançar o quanto puder, sem querer reduzir o dizer deles ao seu discurso.

A hermenêutica filosófica supõe que ultrapassa os pressupostos filosóficos ao dizer que os questiona ao longo de suas análises. Ela pode recair na esparrela teológica ao não ver suas limitações, idiossincrasias: cai em ideologia ao não se ver como ideologia. Nem tudo se baseia, por exemplo, numa relação de pergunta e resposta, como se a pergunta surgisse por si e não como sugestão da resposta que se quer. Conflitos de classe, problemas étnicos, impasses políticos, tudo isso é mais concreto do que apenas uma pergunta abstrata.

Essa hermenêutica tem no existencialismo sua força e sua limitação. Ela é impermeável ao questionamento de suas premissas. Se o Heidegger II, por exemplo, usa reiteradamente a expressão "último deus", favorece a regressão teológica, mesmo que diga que esse deus não poderia ser cristão nem grego. Ignorar a política é uma conivência política. Um grupo como o da "Poética e hermenêutica" podia contar durante os anos da Guerra Fria com o apoio da Fundação Volkswagen, mas esta não deu apoio a simpósios de intelectuais em países como o Brasil, embora a empresa estivesse fortemente representada neles.

Heidegger afirmou reiteradamente que a técnica não pensa. O que ele quer dizer com isso dá para entender. Aí, pensar se dá apenas no parâmetro filosófico. Com isso ele não percebe como a técnica poderia ajudar o pensar em filosofia, que não pode ignorar os avanços da ciência e da tecnologia. Quem tem formação técnica

${ }^{5}$ Kothe, Flávio R. Arte comparada, Brasília, Editora da Universidade de Brasília, 2016. 
tende a ter dificuldades em pensar teoria, em raciocinar de modo abstrato. Sua mente não sabe dançar, não sabe fazer piruetas conceptuais. Não apenas ele tem tais inibições.

\section{A diferença ôntica}

Em geral se faz a primeira comparatística para não fazer a segunda nem chegar à terceira ou à quarta, mas principalmente para não chegar a algo que as supere. Opta-se pelo menor, pelo canônico nacional, como se fosse o máximo, para deixar de lado o único que mais importa por estar aberto ao além do horizonte limitado da crença e do conceito, sendo capaz de constituir como obra o que vá além de preceitos instituídos como se eles fossem todo o conhecimento. Aos profissionais especializados fica difícil entender que aquilo que eles aprenderam com tanto custo e esforço possa não só ser questionado como ser considerado antes um modo de não ver do que de bem perceber o objeto de sua especialização.

Há mais em jogo do que discordância metodológica. Na "primeira comparatística", rastreiam-se influências e fortuna crítica: assim parece tudo resolvido. Ela contém um paradoxo: serve a preceitos como orgulho nacional, patriotismo, moral partidária e de minorias, para justificar obras menores como importantes: não consegue ver suas próprias limitações nem das obras que promove. Ela é prisioneira daquilo a que serve. Parece soberana, defendendo valores maiores, mas faz parte de disputas de dominação que se ornam da arte para se legitimar: ela é dominada enquanto domina. Onde está sua força mora a sua fraqueza. Quanto mais reforçada é pelos interesses a que serve, detentores do poder local, tanto mais fraca se torna como hermenêutica. A semiótica da cultura pode ser um passo avante, desde que ela não seja apenas a aplicação de um esquema a priori de tipos de signo.

Prédios, esculturas, quadros e cidades também são textos a serem lidos. A exegese corrente não se apresenta, porém, como hermenêutica: ela se postula como especialização, propõe sua leitura como única, tende a dogmatizar-se. Isso se mostra em púlpitos de templos e em púlpitos eletrônicos, em salas de aula e comitês assessores, em livros didáticos e revistas especializadas. De tanto esmiuçar miudezas não se pensam mais os fundamentos. Apenas se pensa que se pensa. Não se questionam os próprios pressupostos. Presa a eles, aprisiona o diferenciado, antitético. Quanto mais prisioneira, mais supõe ter a chave da verdade.

Texto é um conjunto de signos e sinais que pode ser decodificado e entendido. Os códigos podem ter conceituados seus componentes. A intelecção pelo código pode ser transformada em conceitos. Os códigos das línguas têm equivalências para os signos. $\mathrm{Na}$ obra de arte, no entanto, não há equivalências. Cada sinal seu é único, sem sinônimo.

Obras de arte são mais que sistemas codificados. Para captar essa diferença, é preciso dominá-los e, daí perceber o que a obra faz mais avante. A comparação entre obras de arte, e não apenas delas com seus comentários críticos, permite discernir melhor o que constitui a diferença ôntica de cada uma.

A obra de arte é e não é texto: é, à medida que vários componentes podem ser analisados em termos conceituais, decifrados em seus códigos; não é, à medida que a artisticidade não pode ser definida por uma fórmula, pois depende de algo inominável, que contém sensação, sentimento, intuição, imaginação, liberdade, para acabar transcendendo o horizonte do conhecimento conceitual. A arte não é menos por não ser ciência. Ela é mais, por algo que está além da apreensão conceitual. A ciência é prisioneira do conceito. O cientista, para descobrir algo, precisa ter imaginação criativa, não apenas reproduzir dados. Não é a rotina do laboratório, mas aquilo que a determina, interpreta e vai além.

A comparação é feita mediante análises, mas propicia que seja discernido de modo mais objetivo algo que as transcende. Uma "escola da comparatística" tem meta, tem objeto e tem método. Parece, então, ser ciência. Embora procure ultrapassar os limites nacionais, ela atende a interesses ideológicos: afirmar uma nacionalidade, confirmar a história de um país, legitimar a dominação vigente, fazer propaganda de um credo, endossar as teses de um movimento político, defender uma minoria. Mais importante do que isso é um lado reverso, do qual ela também não fala, pois falar seria se expor: ela não toca nos pontos nevrálgicos encobertos por seu discurso, ela inibe a manifestação do avesso daquilo que por ela se afirma. A rotina técnica, de tanto falar em árvores, deixa de ver a floresta, não vê a quarta margem do rio.

Essa "comparatística" reúne escolas como a francesa, a norte-americana, a eslava, a soviética e outras. Aquilo que parece apenas divergência e contraposição tem um denominador-comum que só se consegue discernir ao se sair do horizonte delas. Essa nova proposição se inicia nelas, quando procuram superar os limites de uma obra, de um estilo, de uma nacionalidade, de um gosto de época. Sendo sua tendência dominante fazer a complementação à história nacional, ela se restringe ao ôntico, evitando o difícil intercâmbio entre duas montanhas distintas: arte e filosofia, e não apenas poesia alemã e existencialismo. Para o voo entre elas é preciso ter asas, que não são dadas a alpinistas. 
Esse outro caminho é mais espinhoso. Ele não tem, aliás, método fixo nem sabe exatamente qual a meta a que quer chegar: se soubesse, já teria chegado. Faz o caminho ao andar. Não pretende submeter a arte a uma filosofia nem fazer da arte uma filosofia maior. A "meta" não é algo que possa ser definido por conceitos, embora precise de todos os conceitos disponíveis e mais aqueles que forem necessários inventar para crescer com a grande obra. Seu "método" não é a priori: pelo contrário, deixa ditar seu caminho pela "natureza do objeto" da pesquisa. Não tem, no entanto, a pretensão de se sobrepor ao "objeto" como um sujeito que acha que pode dispor de tudo.

Não há um ponto exato de partida nem de chegada, pois é preciso estar aberto à infinitude por janelas embaçadas. O único a discernir são sombras e fímbrias, que não estão onde se espera. As formas das sombras são delineadas por réstias de luz. Essa revisão do conceito de verdade não se restringe mais à "alétheia" do ser/estar, mas se abre para o havente que não costuma nos aparecer. Acenam-se aí novas formas de fazer arte, novos modos de pensar. O sugerido é mais amplo e profundo do que o que pode ser dito.

Não se fala mais dos píncaros institucionalizados, do modo como costumam ser apresentados, e sim de passos perdidos e surpresas do acaso. A meta é não ter meta, não ficar preso a fins pré-estabelecidos. Estar aberto ao obscuro e abscôndito exige uma nova linguagem, que ainda não se tem. Passa-se da prioridade da visão para o radar dos morcegos. Abandona-se a pretensão da filosofia em ditar as regras, pois se percebe a limitação do entendimento conceitual, que tende a enquadrar tudo em seus sistemas. Não se aceita mais também a pretensão dos sistemas idealistas em hierarquizar as artes, como se uma obra fosse superior só por pertencer a uma linguagem determinada.

Como isso ficou mais na pretensão do que na prática, foi um passo antes potencial e parcial na direção da hermenêutica filosófica, aquela que pretende ser capaz de questionar seus pressupostos no percurso de seu trabalho, mas sem a prioridade que a filosofia dá ao conceito. Este se torna apenas um instrumento entre outros. O que se busca é uma crescente aproximação com a obra, a aprendizagem de um diálogo entre as artes e com as artes. Se a "comparatística" pode ser perder em detalhes, não vislumbrando potencialidades, - outro caminho pode se distanciar demasiado da comparação. Se a grande arte opera a dificuldade do difícil que ela tem a dizer, seu caráter hermético não é um adicional arbitrário de dificuldade.
Se essa outra via foi pressentida por Nietzsche, Heidegger, Gadamer, Blanchot, Beda Alemann, Peter Szondi ou Paul de Man, ela não costuma ser praticada pelos adeptos das "escolas da comparatística", pois está além dos seus pressupostos restritos ao labor comparativo. Mais que ignorada, ela é até hostilizada. A "primeira" quer preponderar como se fosse única. Ela por si e em si não admite a outra, pois esta é sua negação e sua superação. Ela não pode aceitar o que ela não pode compreender. E não pode porque não quer. Compreender seria assumir como verdade aquilo que nega o dogmatismo dos seus pressupostos.

Gadamer supõe que o conhecimento se opera numa relação de pergunta e resposta. Esta se dá no âmbito do ser/estar. Será que é mesmo assim? A resposta induz à pergunta. Adivinha-se antes a resposta do que a pergunta. A busca para além do horizonte do que está aí disponível não tem pergunta antes da sugestão que vem do além. Não se está falando em iluminação mística, em revelação divina.

A ciência supõe hoje que no máximo em três milhões de anos não vai mais haver vida humana na Terra, já por falta de oxigênio. O planeta talvez habitável mais próximo fica a quarenta anos-luz, uma distância intransponível, por mais que filmes de ficção científica sugiram milagres de velocidade. Na proposição de pergunta e resposta, ficase preso às linguagens estatuídas, às línguas conhecidas. Elas não são aptas a captar o ignoto. Não há razão para supor que a palavra possa ser mais apta do que a música ou o espaço construído.

A hermenêutica filosófica prioriza o discurso e, assim, continua presa à tradição, com a qual pretende romper. A palavra não é garantia de verdade nem de sua busca. Ela serve para encobrir. A palavra pública serve para persuadir e enganar; a palavra privada, para esconder. Ela pode, eventualmente, servir de trampolim para um salto solitário no nada do existente. Religiões ontificam o ontológico, entificam a infinitude, perdendo ambos de vista: servem de cobertor sobre a cabeça, para crianças apavoradas com a grandeza do incomensurável. É preciso retirar da religião a mistificação do transcendental, recobrar frestas em que ele se deixa transparecer.

A "comparatística" trabalha para reafirmar os pressupostos de quem a exerce e escuta, não para questioná-los nem superá-los. Por isso, ela parece tão natural e verdadeira, não sendo uma coisa nem outra. Ela não estuda arte, sua prioridade não é o artístico, embora diga que seja. Usa obras para afirmar valores ideológicos, sem perceber que se trata de uma contradição: a pretexto de estudar arte, está a serviço de uma suposta nacionalidade, religião, moralidade, 
minoria, etc. Exatamente por não perceber a natureza do artístico supõe ser dona dele. Faz parte da utilização de elementos estéticos para finalidades não artísticas

\section{Poesia e filosofia}

Filosofia é dúvida que busca resposta, o que está longe da habitual pretensão de poder, já porque este se dá num espaço ridículo. Essa busca incessante não chega a uma explicação última, mas por isso mesmo continua tentando. $E$, se não puder falar, trate de escrever; se não puder publicar, trate de sonhar. Essa ânsia da razão é uma busca de liberdade. Busca-se o que não se tem; tem-se a ânsia porque a razão não prepondera.

A poesia é uma intuição dessa busca, numa linguagem cheia de imagens e sonoridades. Platão é um poeta que escrevia sobre temas filosóficos: se não se entender sua forma literária, não será compreendido. Construía ficções para pensar. O que ele, em seus diálogos, procurava sugerir não pode ser resumido numa frase.

Poesia e filosofia procuram dar nome ao inominável. Isso beira o místico, mas deveria se afastar da mistificação. Um segredo só pode ser dito em segredo, como sugeria Friedrich Schlegel: "Já o conceito, o próprio nome da filosofia e toda sua história nos ensinam que ela é um eterno buscar e um não-poderencontrar; e todos os artistas e sábios concordam que o mais elevado é indizível, ou seja, em outras palavras: toda filosofia é necessariamente mística. Quão natural: pois ela não tem nenhum outro objeto, e não pode ter nenhum outro, senão aquele que é o segredo de todos os segredos: mas um segredo só pode e só deve ser comunicado de modo repleno de segredo. (...) Daí finalmente a alegoria na expressão da perfeita filosofia positiva, a identidade de sua doutrina e do seu conhecimento com a vida e a religião, e a transição de sua perspectiva para a poesia elevada; mas daí também finalmente aquela forma da filosofia que, sob todas as condições e em todas as circunstâncias, é sua forma permanente e legitimamente essencial: a dialética." ${ }^{6}$

Famoso por ter sido epígrafe da Teoria estética de Adorno é o seu dito: "naquilo que se chama de filosofia da arte, falta em geral ou a filosofia ou a arte". Se faltar um dos termos, não se responde ao título. Com a dupla negação se retira o fundamento do que se pretende definir. Há um esvaziamento da proposição, antes mesmo de fazê-la, mas se indica via negationes um novo tipo de percurso.

${ }^{6}$ Friedrich Schlegel. Kritische Schriften, München, Hanser Verlag, 1964, p. 448. Em "O espírito de Lessing a partir de seus textos", na parte sobre "Ernst und Falk", mais especificamente em "Sobre a forma da filosofia".
Ele crê que a forma suprema do conhecimento seja a filosofia, sendo a poesia sua vassala. A ênfase no místico, que tenta se resolver pelo mítico, tende a levar à mistificação, fugindo às questões mais candentes. Para Schlegel, a alegoria se torna expressão da perfeita filosofia positiva. Não existe filosofia perfeita, menos ainda quando se confunde com religião. A alegoria se torna aí a expressão imagética de uma ideia já resolvida pela filosofia, uma imagem carregada de significação que se reduz à exemplificação. Não há identidade entre vida e religião, nem de religião com vida.

A alegoria sugere sempre outra coisa que não aquilo que à primeira vista aparece. Ela foge à identidade, é antes sua negação que sua afirmação. Ela pode sugerir o que não pode ser dito, desde que fuja ao caráter convencional e socialmente imposto da linguagem das figuras alegóricas. A alegoria não é, então, a representação concreta de uma ideia abstrata. A figura da Justiça só pode ser entendida se ela não for lida nos termos da linguagem convencional. Só a contrapelo da leitura imposta pelo stablishment é que se pode discernir a diferença entre o que é sistema judiciário e o que deveria ser a justiça.

Nada do que se vê numa alegoria significa literalmente aquilo que aparece, aquilo que se vê, há uma espécie de fantasmagoria pairando sobre a imagem, mas também não é um signo arbitrário, em que o significado não tenha nada a ver com o significante: há uma correlação entre imagem e sentido, sem haver identidade. Nessa diferença se acena uma transcendência, um nada do ser para sugerir um não ser que é, sem ser aquilo que aí está. Ela precisa ser lida a partir do seu nada, uma visão de algo que transcende o que aparece, está nele e não está, é ele e não é. Precisa ser superada, portanto, a definição dela ditada pela tradição metafísica.

Não basta dizer que a alegoria é uma linguagem convencional, imposta em tal e tal sociedade. Essa é sua ideologia, sua fachada, seu "pseudos". O que está em jogo é algo que fica além do horizonte dessa sociedade. A leitura alegórica tende a conduzir a obra de arte a uma significação abstrata, filosófica, como se encontrasse nesta a sua razão de existir. Essa significação convencional pode ser útil para entender o processo alegórico, desde que se saiba ir além dela. Há um gap aí, um buraco, um lapso entre o que aparece e aquilo que se sugere: uma fresta que permite espreitar além.

Assim como, na perspectiva da tradição metafísica, a alegoria é uma aparição concreta de uma ideia abstrata, "transcendental", assim ela também pretende ver no artista e no filósofo aquele que passou pelo mundo das ideias e o traz aos homens como revelação. 
Para Aquino, o belo seria a aparição sensível da verdade, sendo verdade a crença católica. Anterior e superior a todo ente concreto é algo espiritual, que impregna tudo. A concepção da arte no neoplatonismo é alegórica: concretização da ideia.

Sócrates, no final da República, sugere, no entanto, que o mundo das ideias não é um mundo primeiro, do qual a realidade seria uma cópia (conforme crê também a tradição cristã, sendo a mente divina esse "mundo das ideias"), mas um mundo "copiado", como que "refletido" no imenso espelho da mente. Ora, o espelho da mente seria, no máximo, uma sinédoque miniatural da realidade, pois concentraria tudo na reflexão do sujeito, como se o mundo começasse e terminasse com ele. Ninguém "reflete" tudo, pensar não é só copiar ídolos, pequenas imagens de coisas externas: fazer arte, também não. Revisar a alegoria implica revisar o platonismo subjacente à sua definição. É preciso pensar a diferença entre o exposto e o proposto para ver nela a fímbria pela qual pode aflorar o que transcende o rotulado por conceitos.

O belo não precisa se validar como "veículo da verdade filosófica", como se ele tivesse em outra instância que não ele mesmo a sua validade. A teologia da arte crê que a obra só vale como expressão concreta da "verdade religiosa". O belo vale por si, atrai atenção para si por si. Não depende de outra instância para se validar. A arte não existe para que haja filosofia da arte. A poesia não existe para validar a teoria literária. Esta não é apenas uma página da estética. Pelo contrário, o que consegue aflorar melhor o fundamento do poético ajuda a aflorar o pensamento que vai além do platonismo cristão. A teoria literária não é mera serva da filosofia, pois pode ir por outros trilhos mais longe.

Filósofos e grandes poetas são raros: surgem em poucos lugares, não cabem muitos em um século. Não há oposição entre poesia e filosofia, mas transição. Quando a filosofia alcança os limites do conceito, ela procura se expressar por imagens e figuras retóricas, se aproximando da poesia. Grande poesia usa conceitos, mas vai além do conceito: não é aquela que se pode resolver por ele.

Poesia e conceito se aproximam pela palavra. Será que esta é a instância absoluta da presença e presentificação do espírito? Quando se diz no Novo Testamento que em Cristo "o verbo se fez carne e habitou entre nós", isso é exato se Cristo for entendido como um personagem literário, produto da fabulação de alguns escribas, passando a exercer imenso fascínio e influxo por dois milênios, mas não é exato se for concebido, como costuma ser, como um desejo de Deus pai, posto na Terra para redimir os homens, consertando os defeitos de fabricação inerentes ao ser humano. Na expressão bíblica, a prioridade é da palavra, mas o "habitar entre nós" se faz também por pinturas, esculturas, obras arquitetônicas. Ele não é apenas verbo e verba.

A filosofia da arte tem a tentação de resolver a arte mediante conceitos, querendo superar a arte pela filosofia: isso é parte de uma vontade de poder: não pode tolerar o mistério, a resistência que a obra oferece ao entendimento. Concentrando-se em obras consagradas, ela deixa de examinar o que é socialmente relevante e deve ser enfrentado com conceitos: narrativas triviais, obras religiosas, propaganda política, engajamento moral, industrialização da cultura. A pretexto de se preservar para o mais elevado, ela evita problemas políticos agudos, onde teria de enfrentar as reações do poder. Quando o filósofo busca o poeta, quer encontrar nele chaves para o seu pensar. Tende a submeter o texto ao filtro das próprias preocupações, deixando de lado o que não lhe convier e impondo a sua visão.

A crítica literária tem dificuldades de se alçar até o voo filosófico, ela tem de aprender a não se restringir ao maravilhamento diante do poema, assim como a filosofia precisa aprender a não atribuir ao texto o que pode não estar nele. Nesse sentido, são atividades complementares. Pode ocorrer a dialética negativa, em que cada uma nega a seu modo o texto, seja por ir além dele, seja por ficar aquém. O próprio texto literário pode estar, no entanto, abaixo de suas possibilidades. Por isso, é preciso que apareça outro poeta, outro artista que dê esse passo adiante.

\section{Arte e verdade}

Kant retomou a proposição de Wolff e Baumgarten, no sentido de ultrapassar o horizonte limitado do entendimento conceitual por pulsões do sentimento e da imaginação. Abriu, com isso, caminho para o romantismo, a semiótica e a psicanálise. Intuição, imagem, devaneio, sonhos, sentimentos, pulsões do inconsciente foram vistos como forma do saber, mas como a ilusão de serem por si mais verdadeiros. Eles podem enganar tanto quanto conceitos. A desconstrução foi um progresso, por admitir um grau maior de perplexidade, mas de que adianta acumular ruínas sobre si mesmo? Desconstruir deve servir para se chegar a um constructo melhor, com mais fundamento, resistência e beleza.

Ao postular o juízo sintético ao lado do analítico, no mesmo plano, Kant fez uma revolução filosófica: abriu caminho para a dialética, que ele próprio ainda não soube operar bem, à medida que a restringiu às 
aparências, como fornecedora de conteúdos a formas analíticas. O conservador prefere não admitir que tudo está sempre mudando e que por toda a parte impera a contradição, quer se queira quer não. A dialética constitui uma abertura da lógica ao caráter contraditório da realidade.

Ao admitir que a antítese se manifeste, questiona e ultrapassa o caráter impositivo da tese, o caráter limitado e artificial da lógica formal analítica. Ao se abrir para algo ainda mais amplo que o jogo formal, ou seja, que na realidade tudo é mutante, presume que tudo contém a sua própria negação, que cada vetor é determinado por diferentes fatores, que o tempo é constitutivo das coisas e do processo de conhecimento. Sugere um pensar que precisa tentar continuamente se ultrapassar para ser realmente um pensar. Mesmo que não evite recaídas na ontologia do ser em detrimento do devir, ela admite a complexidade da vida, a infinitude: precisa estar aberta para o inesperado e o antitético, para as limitações do pensamento, sem ter a pretensão de resolver tudo de modo definitivo. Por isso, está cada vez menos disposta a se mancomunar com o dogmático e o absoluto.

Para Nietzsche, o que se observa na realidade é que as coisas mudam com o tempo. A lei científica tem a pretensão de ser imutável, eterna, universal, como um saber divino. Há, portanto, uma incompatibilidade entre a realidade e o conhecimento. Fazer dela apenas o permanente é falsear sua natureza. A ontologia como estudo do ser que permanece não pode ser o fundamento de uma realidade mutante.

Com que conceito de verdade e de arte está se operando? Não pode ser uma verdade apenas conceitual, como postulada pela tradição metafísica. Não são apenas verdades para dançar. Hegel definiu, na Pequena Lógica - contrariando a si mesmo - a verdade como a percepção do objeto em suas múltiplas determinações. Como é possível saber que se chegou à última das determinantes? Se isso não é possível, se sempre pode aparecer mais um fator explicativo relevante antes não considerado, se os vetores determinantes estão sempre mudando, então a verdade é, a rigor, uma utopia.

Hegel gostaria de chegar ao absoluto, cuja única razão de existência não pode ser aventar o relativo, mas para chegar a ele deveria poder conhecer todos os vetores existentes e antecipar ainda os vindouros. Só sendo um deus onisciente para isso, e ele é uma ficção. Nem mesmo se pode definir a que distância se está da totalidade do objeto, para saber quão distante se

${ }^{7}$ De Man, Paul. The resistance to theory, Minneapolis, University of Minnesota Press, 1986. estaria do conhecimento absoluto. O totalitário acha que conhece tudo o que importa, mas ele é escravo e prisioneiro da sinédoque. O espírito totalitário é o que está menos próximo do que pretende. A ficção poderia ser mais verdadeira que a ciência, já que ela ao menos reconhece ser ficção e não tem a pretensão de reduzir a realidade a uma dimensão apenas quantitativa.

A obra como que se fecha sobre si mesma não apenas porque a conclusão já está contida no começo, como se ela fosse escrita de trás para frente enquanto está sendo feita do início até o fim. Dentro da boa obra, todas as partes remetem a todas as outras, elas estão conectadas entre si não apenas como uma sequência linear e sim como plurideterminação em vários eixos de todas as partes entre si. Cria-se um "ritmo" mais complexo que a sequência linear de compassos. Isso não ocorre de modo uniforme ou flutuante, mas com ênfase em certas conexões, como se fossem vigas de uma construção. Em suma, a obra constitui um sistema, mas o caráter sistemático da obra não faz com que ela necessariamente seja artística. O sistema se serve de andaimes para se construir: eles ainda não são o artístico.

Quando um personagem, um local ou topos reaparecem ao longo da obra, eles reevocam, sempre que reaparecem, as outras vezes em que aparecem, tanto para a frente quanto num movimento retrospectivo. Ainda mais: geram um movimento sinuoso de conexões com elementos similares e com os contrastantes. Isso forma um trançado íntimo, que rompe a linearidade. Há um "ritmo" polivalente, a gerar um entremeado complexo no interior da obra. Quando o idêntico reaparece, ele evoca e invoca outras vezes em que já apareceu e, ao mesmo tempo, prepara as vezes em que irá novamente aparecer: com isso ele deixa de ser idêntico consigo mesmo, pois insiste na semelhança com as outras vezes em que reaparece, com novas nuances de significação. Isso não impede certa sequência linear, mas também rompe com ela: é uma reiterada construção além da linearidade, com entrecruzamentos em várias direções.

Além desse processo de evocação por similitude, como se a obra perfilasse dentro de si vários eixos paradigmáticos, tanto pela forma quanto pelo conteúdo, numa associação de ambos, há outros tipos de evocação a serem considerados: 1) a retomada por contraste, o que, mediante uma contraposição, vai reevocar a tese já proposta; 2) a presentificação por ausência, uma presença que não é mera imaginação arbitrária do receptor, mas algo propiciado pela estruturação da obra. O mau exegeta não a percebe. Tal ausência abre espaço para outra obra dentro da obra, capaz de superar a antevista, ou fecha um espaço mediante uma lacuna, quando a imitação não assume o 
espaço possível. O bom hermeneuta percebe a presença dessa ausência e, assim, consegue entender melhor a configuração daquilo que Ihe foi proposto pelo autor.

Paul de Man, que conhecia bem a tradição filosófica e as escolas críticas modernas, propôs que o artístico é algo que se oculta além das técnicas de construção textual, que ele existe como negação de todos os truques e recursos de construção. ${ }^{7}$ Os "truques de construção" não justificam por si o artístico: pelo contrário, sua abundância é sinal de que ele não está aí. Muito enfeite é sinal de falta de beleza singela.

A grande obra de arte é simples, sem ser simplória: ela é a melhor solução para aquilo que nela se quer expor. Ela não acrescenta dificuldades, mas também não facilita, pois é algo complexo o que ela tem a registrar. Um artesão precisa caprichar rigidamente no metro quando não tem suficiente senso de ritmo. Precisa seguir com rigidez a partitura quem não tem a liberdade criativa do artista, capaz de propor combinações jamais ouvidas.

Será que a proposta de uma "estética do nu", um despojamento calculado, pode ser algo mais pertinente à essência do artístico? Para surgir algo assim, como movimento de vanguarda, é preciso haver antes um "cansaço" com os modelos anteriores. Trata-se, portanto, antes de um modo de elaborar obras do que a essência do artístico. Assim como no rococó se adicionavam muitos ornamentos ao longo da obra, na "estética do nu" tem-se o princípio do despojamento. Ninguém pode ser "naiv" sem conhecer a tradição das artes. Se fosse apenas isso, o transcender os "truques de construção" seria apenas mais um manifesto, um apoio a determinado gosto, rejeitado por outras escolas em outros momentos.

O que se quer dizer é, no entanto, que as grandes obras guardam em si uma "graça", uma beleza que não pode ser reduzida a termos técnicos. As boas obras, embora revelem amplo domínio técnico, constituem nelas e por elas algo que vai além do horizonte técnico. Isso continua sendo um mistério, algo que o gosto apurado vivencia, mas não pode dar plena explicação mediante conceitos. Estes precisam ser esforçados e forçados ao máximo para dizerem o que for discernível por eles, mas há algo mais na grande obra que se percebe pela sensibilidade e pela imaginação, pelo confronto com outras obras, pelo sentimento e pela experiência de vida.

É algo que o bom conhecedor percebe quando existe, mas percebe também quando deixa de existir. É uma tendência inata ao homem de perceber o belo, o artístico.
Essa tendência inata precisa de muita cultura e muito cultivo para conseguir se desenvolver. É como o talento que nasce com o artista, mas que se atrofia e se perde se não for trabalhado e desenvolvido com muito labor. Comparar obras de arte é um percurso nessa direção.

Alberti entendeu que perfeito é algo ao qual nada se pode acrescentar, tirar ou modificar sem que fique pior. Isso vale tanto para uma obra prima quanto para uma máquina. Qualquer instrumento pode ser avaliado assim. A perfeição não caracteriza a arte. Uma obra pode não ser perfeita e mesmo assim ser arte. Algo é perfeito nos termos do que pode ser feito com determinados materiais e técnicas, mas já não ser mais quando estes se modificam. Um instrumento de tortura pode ser perfeito em suas funções, como um clipe. Isso não o torna arte.

Querer definir o artístico pela capacidade de transcender o aqui e agora da gênese da obra é um critério válido que pode se transformar numa falácia. Nem tudo que permanece é arte, mesmo que pareça artístico. Um Estado pode se apossar de obras de autores nacionais e impor trechos delas nas escolas. Assim, elas estão nas bibliotecas, enchem as caixas registradoras dos editores e livreiros, respingam as contas bancárias dos professores, mas podem não ser arte. Sofrem de antemão o prejuízo de serem selecionadas segundo interesses limitados no espaço e no tempo, com a ânsia de impor isso como algo universal e atemporal. São promovidas como ideologia. A arte é, porém, a morte da ideologia, pois ela sempre (se) constitui (n)um horizonte que transcende as limitações ideológicas.

Uma obra pode atender a esses e outros requisitos que caracterizam grandes obras, e não ser uma grande obra, não ser sequer arte. Isso não quer dizer, porém, que uma obra vai se caracterizar como grande arte só porque não atende a nenhum requisito. Essa seria uma poética pelo avesso, uma nova falácia. Um grande artista domina a técnica, sem ser dominado por ela. Ele a usa com liberdade, encontrando soluções que surpreendem os conhecedores. E inventa técnicas conforme o que ele quer criar. O artesão menor, esse é controlado pela técnica, na qual ele se perde. O leitor menor fica dominado pela obra; o grande leitor consegue discernir o horizonte limitado da obra menor e admirar a amplitude da maior.

A suposta concepção romântica de que a obra teria nela mesma o impulso para sua superação pela crítica não corresponde à maior parte das obras. Poucas têm uma metalinguagem crítica inserida em seu "discurso", como um modo de elevarem sua autorreflexão para um patamar superior. Aliás, quem precisa isso não está se sentindo à vontade na utilização dos elementos 
artísticos para se expressar. Essa concepção aponta para uma suposta superação da arte, que passaria a ser substituída pela conceituação como instância mais elevada, um patamar para o qual o artístico seria uma escada. Isso é não entender arte.

Se tal concepção vingasse, não haveria, a rigor, colaboração entre arte e teoria, mas uma guerra mortal, em que o conceito correria atrás das obras de arte como um predador. A filosofia seria o vampiro da arte. Se a obra é, no entanto, um vampiro que vive do sangue dos artistas, os artistas só conseguem, por sua vez, respirar pelo espaço que conseguem criar em suas produções. $A$ obra só sobrevive como arte se consegue ser maior que os ataques do conceito. Se a pobre donzela precisasse proteger-se com os alhos do hermetismo e os santos óleos da sacralização para não ser sugada em meio à noite, então ela talvez não merecesse sobreviver.

\section{O belo e o universal}

A preponderância do universal sobre o singular marcou o positivismo como tendência metafísica. A estética neoplatônica define a alegoria como a aparição concreta de uma ideia abstrata, como se "universais" se encarnassem em entes singulares. Tais "universais" são antes crenças do que identidades definíveis. Quanto mais ampla a abrangência deles, mais vazios se tornam. No fim acabam se contradizendo, como o Ser que não é nenhum ser.

Na grande obra de arte o problema não é a preponderância, e sim a conjunção do "singular" com algo que seja mais "genérico", a intersecção do ôntico com o ontológico, a união paradoxal e hipostática que é resolvida como se um aspecto pedisse o outro. Essa dialética concreta nem sempre é percebida, mesmo em teorias que pretendem falar em nome dela. Presas à tradição metafísica, são menos revolucionárias do que supõem. A questão já se deslocou, entrementes, para a estrutura dessa metafísica, da qual derivam as conceituações.

Quando se diz "singular", tem-se como contrapartida o "plural", no qual se singulariza a obra, afastando-a das demais. Para fazer parte do plural, ela precisa se reunir a elas, o que gera um duplo movimento, contraditório. Em toda leitura se tem a comparação com outras obras e com o que não é arte. O termo "singular" não é, portanto, adequado, pois a singularização tem subjacente uma plurificação.

Quando se diz "particular", tem-se como contrapartida o que é "público". O que aí está em jogo é algo que se supõe que "o público" possa perceber e que não seja da esfera íntima, privatissime, de alguém ou algo. Dever do signo é caracterizar para outrem o que nele se quer expressar. Quando se diz "universal" pressupõe-se um "universo", ou seja, um todo fechado e infinito. Ora, nenhum todo é infinito, nenhum infinito é fechado. Não se pode exigir "necessidade" quando o que se formula pretende ir além do horizonte do que se supõe conhecer. A língua portuguesa, por não ter tradição filosófica, é carente de adequada terminologia. Quem não pensa bem também não escreve bem.

Arte não é só beleza. Ela pode conter o grotesco, o feio, o chocante, o desagradável, etc., sem que isso tudo sirva apenas para realçar belezuras. O belo não é a chave de toda a arte. O belo não é a verdade camuflada (ou vice-versa), pois ela não se reduz a crenças e ao conceitual. Baumgarten propôs uma "verdade da lógica estética" ao lado da "verdade metafísica": esta operaria com pensamentos abstratos e juízos lógicos, enquanto aquela seria ligada ao sensorial, ao afetivo, ao imagético. Fichte observou, em palestras de 1804, que na intuição ainda não se tem o conceito nem propriamente a imagem: o conceito é o produto e a morte da intuição; a imagem precisa ser intuída por uma cópia para ser percebida como imagem intuída.

É preciso haver uma intuição da intuição para se perceber a intuição, passando-se a conceituá-la como tal; é preciso ter uma imagem da imagem para que se tenha uma noção da imagem. Quando essa noção se converte em conceito, morre a imagem como pura imagem. 0 conceito é a perda, a morte da imagem intuída. Kant observou que há na mente, no que se poderia chamar de inconsciente, um impulso esquemático, no sentido de converter intuições vagas e conceitos flutuantes em imagens que permitam concretizá-los, discerni-los melhor. As grandes obras são produto dessa capacidade de esquematização imagética.

O que origina tanto a imagem quanto o conceito é a intuição, que é uma luz que surge na mente de modo espontâneo. A imagem não precisa ser visual. O que origina a intuição é inconsciente e imprevisível. Não basta dizer que ela se origina do inconsciente, pois este não existe como tal sem o consciente. Ele não pode ser apenas uma consciência inconsciente, um consciente que não está consciente. Um não é o mesmo que o outro pelo avesso. Se ele é inconsciente, ele é o que o consciente não pode saber que seja. Supor que seja uma consciência inconsciente seria projetar nele uma identidade que não consegue captar nem definir qual seria sua diferença específica.

Se há duas verdades, não se pode apenas supor que a verdade estética está para o corpo assim como a verdade metafísica está para o espírito, pois isso já é separar em dois membros o que é basicamente 
unidade. Onde se daria, no entanto, essa unidade das duas verdades? Qual seria a mediação que as uniria?

A tradição metafísica costuma ignorar a verdade estética, assim como há "artistas" que ignoram a metafísica. Quando se quer no estético um modo de representar "verdades metafísicas", apenas estas são consideradas verdadeiras. Isso transforma a alegoria, entendida como representação concreta de uma ideia abstrata, em cerne da estética. É como se as artes fossem apenas o uso de diversas linguagens para expressar algo que já preexistiria de modo abstrato, seja no mundo das ideias, na mente divina, no inconsciente coletivo ou num sujeito transcendental.

A "verdade metafísica" é, por vezes, apenas expressão de "verdades da fé": crenças, convicções irracionais. Quem crê não crê que crê: ele está convencido de que é real e verdadeiro aquilo em que ele precisa acreditar exatamente porque não é racional. Isso leva a contradições quanto ao que se pode admitir em termos lógicos. Trata-se, sobretudo, de uma linha de argumentação que serve tanto a crenças religiosas quanto a suas traduções laicas.

O corpo pode se enganar tanto quanto a mente. Imagens podem estar tão erradas quanto os conceitos. Nenhuma traz na testa: "eu sou a verdade". Se trouxesse, menos ainda se poderia confiar. As imagens de propaganda procuram se passar por verdadeiras, enquanto, com disfarçada astúcia, repassam interesses mal declarados. Ver na obra a representação concreta de uma ideia abstrata ou ver nela algo que remete a universais faz da alegoria e do símbolo figuras estratégicas da estética metafísica. Também os conceitos não são verdadeiros por si.

Diferentes dos conceitos, imagens simbólicas e alegóricas tendem a ser plurívocas. Mesmo que as simbólicas procurem remeter a uma significação conecta em outro plano, como se fossem a chave para acessá-la, elas podem ser lidas de modo a abrir espaço para significados latentes; mesmo que se pretenda que as imagens alegóricas tenham apenas o sentido socialmente convencionado e imposto, há uma contradição entre seu significado literal e aquilo a que remetem, o que abre espaço para leituras até contrárias ao sentido convencional. Não são sentidos infinitos. Se fossem, não teriam sentido.

O que pode significar tudo, não significa nada. O ambíguo, o sarcástico e o irônico funcionam quando os diferentes sentidos são captados. O plurívoco e o polissêmico apresentam alguns significados analisáveis, e outros que ficam em aberto, latentes, que podem vir a ser conscientizados.
Quando se faz a aproximação de obras, por identidade ou por contraste, para detectar suas significações, a aproximação já enfatiza certos sentidos em detrimento de outros. Ela como que constrói a priori aquilo que ela pretende que seja lido a partir da leitura que nela se registra. Engana a si se não consegue desconfiar do procedimento. Por isso, ela precisa dar mais um passo, fazer um novo confronto, para encarar tudo de outro ângulo.

Verdades abstratas têm significações concretas. Que elas próprias escondem. A verdade da verdade metafísica é, nesse sentido, uma verdade estética, aquilo que se apresenta de modo concreto aos sentidos. Sobre esta se pode construir aquela. A cavalidade do cavalo está em todos os cavalos, mas nenhum deles é O Cavalo. O cavaleiro que anda a cavalo se esquece da cavalidade e até do cavalo.

A verdade estética não está para o servo ou proletário apenas como a verdade metafísica está para o senhor de terras ou o capitalista. A "classe alta" esquece-se da baixa, sim, e quase só se lembra dela quando esta deixa de prestar serviços. A "verdade estética" não é apenas o cavalo da metafísica. Não há separação entre corpo e alma. Há percepções sensoriais inconscientes, há conhecimento por afetos, tato, eflúvios, que somente são tornados conscientes para que se reflita melhor. Os afetos afetam o juízo inconsciente no ato de enquadrar no âmbito do raciocínio abstrato e formal.

Parece que artistas sempre há onde homem houver. A arte surge como um modo de articular "conhecimentos" que não podem ser expressos em conceitos. A verdade estética não é, portanto, mera "ancilla metaphysicae". A verdade de uma imagem (visual, sonora, olfativa, etc.) não está no conceito sobre ela, portanto numa consciência que seja derivada. Está nela mesma, e é de natureza diferente do entendimento conceitual e raciocínio abstrato. A verdade precisa estar na própria verdade. O que se procura com o conceito é fazer a imagem falar. Ela só fala porque nela há voz: ela tem algo a dizer que a fala conceitual não diz. O que se procura nessas imagens é o que o conceito não consegue. A imagem que apenas apresenta o conceito é uma ilustração.

\section{O reverso negativo}

Quando se analisa uma obra de arte como sistema, procura-se entender de modo imanente seu princípio de organização, examinando-o desde dentro, em sua arquitetura interna. Assim como só se entende melhor uma obra de arte quando se capta e vivencia a tensa emoção nela estruturada, só se compreende o âmbito e a natureza da 
dominante quando se consegue escapar ao seu fascínio, vendo-a de fora, como coisa estranha. Para ver o imanente, é preciso ir além dele. Só enxerga os limites de algo quem foi além deles. Para se ascender à ideia, monta-se um antissistema à dominante da obra e, ao se verificar a sombra projetada por ela, constrói-se por contraste um campo interno alternativo, que permite uma leitura do que se constitui em seu avesso.

É como se a obra contivesse outras obras potenciais em si. Pela comparação da dominante com as alternativas virtuais, ou seja, pela comparação da obra com ela mesma enquanto potencial de obras, pode-se entender melhor o que ela é. É uma leitura pertinente ainda que impertinente, uma leitura "inversa" capaz de desvendar a obra pelo reverso, decifrando a aura como encobrimento de um discurso reprimido, não proferido, excluído pela dominante, que pode ser lida inclusive como perversa ao sublimar a repressão. O fato de uma obra de arte abrigar em si um antissistema é um princípio de liberdade e de superação de suas limitações que ela articula em si. Da grande obra não se faz apenas uma interpretação diferente, mas captam-se tensões e sugestões não percebidas antes. A boa hermenêutica dá um passo adiante da obra para chegar a ela através dela.

A assertiva estética não é neutra nem fica fora de comprometimentos com classes, instituições sociais, valores éticos e outros poderes. O silêncio também não é neutro. O que se deixa de dizer é mais que o reverso do que se diz: é a passagem para um horizonte que transcende o dito e o silenciado. Só se entende o dito quando se tem noção do que foi silenciado, pois este constitui a moldura daquele. Onde há poder nunca há plena liberdade; onde não há nenhum poder, não há liberdade nem estrutura organizativa; onde não há poder não se consegue fazer nada com a liberdade.

O poder sempre exerce algum veto sobre a investigação científica, o pensar filosófico, a experimentação artística: quem exerce o poder não exerce essas atividades. Ele precisa se exercer com um ponto de vista aquém daquilo que se pode imaginar. Dizer que o sujeito pode pesquisar e experimentar como quiser, desde que dentro das normas da religião, do partido, da classe, da raça ou do Estado, é contraditório, é negar de fato o que em teoria se pretende estar permitindo.

Uma alternativa hermenêutica é não privilegiar como modelar nenhuma das obras em exame, mas acenar para outra obra potencial, ainda não feita, da qual textos como os apócrifos bíblicos seriam balizadores de um percurso possível. Conjugando-os à interpretação criativa acena-se para um texto virtual, que não foi explicitado por nenhum deles. Isso também não é a exegese paranoica de Salvador Dali, na qual se subverte a leitura habitual, fazendo uma exegese fantasiosa, embora viável, que revela quão frágil é aquela. Ela converte a obra em outra obra, que tem o potencial de desvendá-la pelo avesso. Isso pode se converter em algo que não é crítica usual, mas pode ser uma ficção ensaística.

Quando se diz que o coração tem razões que a razão desconhece, significa que a "lógica formal" não esgota o verdadeiro e que ela pode não ser consistente. Esta lógica está presa ao entendimento conceitual. Num conceito pode ser subsumido um número infinito de entes, mas ele próprio é finito. A razão tem uma abertura para a infinitude, algo que transcende o entendimento conceitual analítico, e faz com que as ideias sejam necessariamente contraditórias, constituindo um esforço da mente em ir além do hábito de operar apenas com finitudes.

O estudo da arte tem um lado de ciência, com tudo o que o conceito permite, mas também é um "ofício" no sentido de que em cada caso é preciso decidir qual é o caminho mais correto, já que a verdade parece ser o mostrar-se do objeto. É possível perceber leis em cada uma das partes e no todo, mas tais leis não esgotam a obra. Elas precisam antes ser induzidas no estudo particularizado do que aplicadas de fora e deduzidas de princípios (tanto mais dogmáticos quanto mais problemáticos). Assim como a literatura comparada é um passo na direção de uma "ciência da literatura", um passo além das literaturas nacionais na busca da totalidade, também a arte comparada é um passo na direção de uma "estética" mais objetiva, não presa aos padrões de uma época ou lugar. Quando é definida, porém, como "disciplina", ela assume o caráter de um "adestramento do conhecimento", que é incapaz de captar o caráter "indisciplinado" da criação e da fruição artística.

\section{Do permanente}

$\mathrm{Na}$ arte se procura preservar o que merece perdurar por mais tempo, algo que deve ser extraído e retirado do fluxo provisório das coisas por ter significação profunda em outras épocas e regiões. Com o tempo, as obras são relidas de tal maneira que elas já não são mais as mesmas, idênticas ao que elas já foram para outros. Obras que parecem inquestionáveis por longos períodos podem ser esquecidas. Grandes autores, como Homero e Shakespeare, foram esquecidos e desconsiderados durante séculos. Os deuses de hoje são o olvido de amanhã. Os olvidados de hoje continuarão em geral olvidados depois de amanhã. 
Embora os fatores que determinam mudanças de estruturas axiológicas sejam de natureza histórica, a história real é menos uniforme do que pretende o discurso dominante. O que não significa nada para o poder atual ou o que ele vê com maus olhos consegue às vezes sobreviver e ressurgir noutra época ou região como tendo valor. A arte é um espaço para manifestar inquietações e diferenças. Nela se projeta o desejo de que o melhor perdure. Trata-se de um desejo encorpado na obra, não de um fato. Ela administra o desejo, encapsulando-se. Constrói muralhas ao redor de si, distanciando-se do mundo. Assim ela se torna um fato, sem que declare que pretende ser melhor. Diante de circunstâncias hostis, o colecionador tenta construir um muro de contenção com a beleza que junta. Tem nela refúgio e consolo, mas acaba refém dela, prisioneiro do que nela se nega.

O entendimento conceitual permite compreender aspectos das obras, mas estas induzem ao confronto entre elas. Pela comparação se entende a diferença de uma obra, delineando sua identidade por contraste em relação a obras com as quais ela tem relações de semelhança e diferença. A comparatística é usada para entender essa diferenciação, mas ela deve ser objetiva no método. Alhos e bugalhos se comparam sim, pois uma parte está reelaborada na outra; não se compara, porém, apenas o que um sujeito acha que se pode comparar. Não se trata de associações arbitrárias e sim de correlações fundadas, embora o fundamento da apreciação se encontre na vivência individual da obra.

Para se chegar à verdade é preciso que a coisa tenha a liberdade de se mostrar plenamente, assim como o sujeito precisa ter a liberdade interior para permitir que ela se exiba em suas diversas dimensões. O que está na coisa não é ditado pela consciência, assim como algo é belo ou não é só porque alguém supõe que seja ou deixe de ser. Se o gênero artístico e a natureza da coisa fossem ditados apenas pela "consciência do receptor", então se tornaria arbitrária a relação entre a função estética e as demais funções, e a arte seria redutível a funções.

Por que a ficção pode ter a pretensão de ser mais verdadeira do que religião? A religião finitiza o infinito, para poder se apresentar como voz da infinitude e assumir o poderio e as benesses da particularização. Ela se apresenta como o que ela não é. A ficção tem ao menos a sinceridade de se apresentar como ficção, sem a pretensão de ser a realidade nem a última palavra que possa ser dita sobre qualquer assunto. Ela é mais verdadeira por não querer se passar como realidade, ainda que ela reproduza aspectos da realidade. Para ser verdadeira, ela não pode ser apenas cópia, pois precisa modificar e transformar dados referenciais para conseguir imprimir-Ihes cunho significativo.
A filosofia da arte também considera a obra como um instrumento, mas da filosofia, para a exposição do que ela considera ideia: usa a obra como trampolim para chegar ao espírito absoluto (que não existe). Nesses casos, a liberdade da obra não existe, ela é atrelada a interesses e pontos de vista alheios, é usada para reforçar preconceitos. Além de poderem ser arte arquitetônica, templos podem abrigar obras de arte, até obras que sejam capazes de ir além do horizonte da propaganda religiosa, assim como obras postas em palácios para consagrar a realeza podem ser apreciadas fora dos vetores que determinaram sua existência.

Não se trata, porém, de mera alteração de "dominante", seja externa, pela mudança de regime política, seja interna, pela passagem de obra decorativa a artística. Esta é uma explicação que parece pragmática, mas é banalizadora. Seria como se a verdade da obra residisse no sentido que lhe fosse atribuído, ou seja, existiria na consciência do autor ou do receptor, individual ou grupal, sendo reduzida às dimensões do contexto. A arte é uma coisa objetiva, pois existe em forma de obras concretas. Nunca foi "metafísica". A obra de arte, como ente corpóreo, resistiu à tendência neoplatônica de glorificar o abstrato, o espiritual, em detrimento do "material". A pretensão hegeliana de chegar ao Espírito Absoluto, sendo a arte algo primitivo por não ser apenas abstrata, é enganosa: não há nada absoluto, não há totalidade, não há espírito sem corpo. A arte não será substituída pelas ciências porque ela tem um alcance reflexivo concreto que não é dado a estas e também não à filosofia.

Não basta um sujeito, individual ou coletivo, por mais poderoso que seja, decretar que algo é arte. Com a astúcia da raposa ou/e a força do leão, pode impor sua opinião. A verdade aí está na vontade do poder. Ele impõe porque isso é do seu interesse: o poderoso é escravo dos interesses do poder. A arte é, no entanto, algo interessante, sem ser interesseira nem se confundir com interesses. No entanto, como todo objeto é mediado pelo sujeito, a alternativa objetiva não é declarar que o sujeito apenas está a reconhecer o que a obra é. Os crentes gregos podiam não perceber o caráter ficcional da obra de Homero assim como a Idade Média não reconheceu a importância dele como artista. Não se reconhecer, por longo tempo e em diversos meios, a natureza e o sentido de uma obra não faz com que ela seja ou deixe de ser o que ela é.

Supõe-se que um "texto sagrado" contenha a revelação de uma "verdade superior". A definição filosófica - de Aquino a Hegel - de que o belo é a aparição sensível da ideia - é teológica: traduz-se o espírito divino, a aparecer no texto sacro, pela aparição da ideia. A grande obra de arte não se deixa reduzir a conceitos, 
crenças ou sentimentos primários. Ela não é um cocho em que o filósofo vai pastar ideias. Ela não é a demonstração de um conceito, de um dogma, de um sentimento fixo. Ela é sempre contraditória, ela é uma abertura para a infinitude. Ela está acima do entendimento conceitual, embora precise de conceitos para ser construída e melhor percebida.

O conceito deriva da seleção de elementos idênticos que se encontram entre entes cujas percepções são diversas: ele é uma definição finita, na qual cabe um número indefinido de fenômenos. Ele é analítico, finito, claro e distinto. A ideia é sintética, com abertura para a infinitude, indefinida em sua abrangência e difícil de distinguir com maior nitidez. O conceito está para o entendimento assim como a ideia está para a razão. Sendo a ideia mais complexa e elevada que o conceito, este não consegue defini-la, pois, quando tentar fazer isso, ele a reduz ao conceitual e trai a sua diferença. A ideia exige mais esforço de apreensão do que o conceito e não pode ser reduzida à lógica formal. Ela não é apenas um conglomerado conceitual e não é uma estrela fixa do mundo das ideias ou da mente divina. Ela envolve sentimento, imaginação, vivência, empatia, disponibilidade, além de tudo o que se exige para chegar ao conceito.
A grande obra de arte ou de filosofia expressa ideias. Ela está num nível raramente alcançado. Há algo de "sagrado" na "ideia", não só pelo respeito que merece como algo único e superior, mas por ser a expressão do mais elevado que o espírito humano é capaz de produzir. O dogma resulta da desistência de pensar. Ele fracassa no esforço de ascender a esse plano mais elevado, porém achando que o alcançou. Quem fica preso a crenças, não tem a abertura e a energia para se alçar a esse nível mais complexo e amplo de visões e vivências. Dizer que a Bíblia é literatura não é rebaixála, mas dar-lhe a oportunidade de ser o que ela é: uma forma de arte, ainda que isso não seja admitido pela exegese religiosa.

A arte comparada poderia ajudar a entender os gêneros e a transição entre eles, já porque compara arte com arte e com não arte. Ela precisa se abrir para o que não é arte, mas opera com signos. Ela precisa passar pelo passo complementar da semiótica da cultura, introduzindo sistemas não artísticos na comparação e entendendo que arte é linguagem não redutível a esquemas formais de signos. As palavras não são signos arbitrários, mas necessários entre os falantes: não produtos de convenções formais e sim das relações entre trabalho e realidade. Imagens podem ser alteradas e sua mentira pode ser proporcional à semelhança que pretendem ostentar com a coisa significada. Não cabe uma hierarquia entre identidade e não identidade de signo e coisa significada, já porque são diferentes por natureza. 
